\title{
Detection of organic carbon in Mars-analog paleosols with thermal and evolved gas analysis
}

3

4
Adrian P. Broz* 1, Joanna Clark², Brad Sutter ${ }^{3}$, Doug W. Ming ${ }^{4}$, Briony Horgan ${ }^{5}$, Paul Douglas Archer Jr. ${ }^{3}$ and Lucas C.R. Silva ${ }^{6,7}$

${ }^{1}$ Department of Earth Sciences, University of Oregon, Eugene, OR 97405

${ }^{2}$ Geocontrols Systems - Jacobs JETS Contract, NASA Johnson Space Center, Houston, TX, 77058

${ }^{3}$ Jacobs JETS Contract, NASA Johnson Space Center, Houston, TX 77058

${ }^{4}$ NASA Johnson Space Center, Houston, TX, 77058

${ }^{5}$ Department of Earth, Atmospheric and Planetary Science, Purdue University, IN, 47907

${ }^{6}$ Environmental Studies Program, Department of Geography, University of Oregon, Eugene, OR 97405

${ }^{7}$ Institute of Ecology and Evolution, University of Oregon, Eugene, OR 97405

*Corresponding author, abroz@uoregon.edu

\section{Key points}

- Trace amounts of organic carbon and organic fragments in Mars-analog paleosols were detected with thermal and evolved gas analysis

- The near-surface horizons of 30-million-year-old paleosols had significantly higher organic carbon content relative to deeper layers

- Radiocarbon dates of approximately 6-14 thousand years before present was consistent with late diagenetic additions of organic carbon

\section{This paper is a non-peer reviewed preprint submitted to EarthArXiv.}


Abstract

Ancient, buried soils, or paleosols, may have been preserved in the geological record on Mars, and are considered high-priority targets for biosignature investigation. Studies of paleosols on Earth that are similar in composition to putative martian paleosols can provide a reference frame for constraining their organic preservation potential on Mars. However, terrestrial paleosols typically preserve only trace amounts of organic carbon. Moreover, the study of terrestrial paleosols is complicated by diagenetic additions of organic carbon, which can confound interpretations of their organic preservation potential. The objectives of this study were a) to determine whether organic carbon in Mars-analog paleosols can be detected with thermal and evolved gas analysis, and b) constrain the age of organic carbon using radiocarbon $\left({ }^{14} \mathrm{C}\right)$ dating. Oligocene $(33 \mathrm{Ma})$ paleosols from Oregon were examined with an instrument similar to the Sample Analysis at Mars Evolved Gas Analysis (SAM-EGA) instrument onboard the Mars Science Laboratory Curiosity rover. Trace amounts of organic carbon and fragments of organic molecules were observed in all samples. Total organic carbon (TOC) ranged from $0.002-0.032 \pm 0.006$ wt. \%. Evolutions of organic fragments co-occurred with evolutions of $\mathrm{CO}_{2}$ from organic carbon decomposition. Like modern soils, the near-surface horizons of all paleosols had significantly higher TOC relative to subsurface layers. Radiocarbon dating revealed an organic carbon age of $\sim 6,200-14,500$ years before present, suggesting there had been late diagenetic inputs of organic carbon. This work demonstrates that near-surface horizons of martian paleosols are a potential high priority location for in-situ biosignature investigation.

\section{Plain language summary}

Ancient, buried soils, or paleosols, may have been preserved in the geological record on Mars. On Earth, paleosols that are billions of years old contain past signs of life (biosignatures), and therefore paleosols on Mars are considered high-priority locations for biosignature investigation. One way to determine the biosignature preservation potential of possible martian paleosols is to examine organic carbon preservation in paleosols from Earth that resemble martian paleosols. The objectives of this work were a) determine whether organic carbon in Mars-analog paleosols can be detected by an instrument configured to operate like the Sample Analysis at Mars (SAM) Evolved Gas Analyzer (SAM-EGA) onboard Curiosity rover, and b) use radiocarbon dating to determine if samples contain recent/modern organic carbon. Trace amounts of organic carbon and fragments of organic molecules were observed in all samples. Like modern soils, the near-surface horizons of all paleosols had significantly higher amounts of organic carbon relative to subsurface layers. Radiocarbon dating revealed an organic carbon age of $\sim 6,200-14,500$ years before present, suggesting there had been additions of recent/modern organic high priority location for in-situ biosignature investigation. 


\section{Introduction}

Paleosols are ancient, buried soils that are commonly lithified into sedimentary rocks. Terrestrial paleosols are a geological record of the atmospheric composition, climate, topography and organisms present before soil burial (Retallack, 2019). On Mars, paleosols, also known as weathering profiles, may have formed in sediments such as basaltic sand or volcanic ash that were subject to subaerial weathering by surface waters (Retallack, 2014; Amundson, 2018; Liu et al., 2021b; Ye and Michalski, 2021) and were subsequently buried and preserved in the geological record. Orbital remote sensing of the global martian surface has detected minerals within Noachian-age (4.1-3.7 Ga) layered sedimentary rocks that are consistent with precipitation-driven pedogenic weathering of mafic sediments (Carter et al., 2015; Bishop et al., 2018b; Loizeau et al., 2018). Noachian sedimentary rocks with spectral signatures of subaerial weathering have been detected in thousands of locations across the surface of Mars (Bishop et al., 2018b). One hypothesis is that these deposits are paleosols (Carter et al., 2015) which are the common products of pedogenic alteration followed by burial. Mounting evidence of global-scale aqueous alteration of the Martian surface during the Noachian (Carter et al., 2015; Liu et al., 2021a) suggests that pedogenesis could have been a critical process early in the planet's history. As such, paleosols have been recently named a high priority location for biosignature investigation (Bishop et al., 2018a) and Mars Sample Return (Beaty et al., 2019), but the biosignature preservation potential of paleosols with Mars-like mineralogy remains poorly constrained (Horgan, 2016).

On Earth, soils are highly habitable environments. Modern soils are teeming with microbial biomass, often averaging $10^{10}-10^{11}$ bacterial cells and $10^{3}$ and $10^{4}$ species per gram of soil (Raynaud and

94 Nunan, 2014). Modern soils also contain more organic carbon than global vegetation and the atmosphere combined (Lehmann and Kleber, 2015; Dynarski et al., 2020). Similarly, Earth's oldest soils also appear to have been highly habitable environments. Many Precambrian ( > $541 \mathrm{Ma}$ ) paleosols contain organic carbon and other chemical biosignatures that are thought to be remnants of surface biomass (Matthewman et al., 2012; Kremer et al., 2017; Liivamägi et al., 2018; Broz, 2020). Furthermore, Archean (>2 Ga) paleosols contain filamentous organic carbon and organo-mineral complexes possibly derived from cyanobacterial mats on the soil surface (Rye and Holland, 2000; Watanabe et al., 2000). modern soils, marine shales, and lacustrine rocks (Retallack, 2019). Organic carbon losses during

103 diagenesis can reduce the organic carbon content of paleosols by up to two orders of magnitude relative to 104 their modern soil counterparts (Broz, 2020). Severe losses of organic carbon are most common in 105 paleosols that originally formed under oxidizing, well-drained conditions (Retallack and Mao, 2019). In 106 general, oxidized paleosols typically contain only low amounts $(<0.1$ wt. \%) of organic carbon (Broz, 
107 2020). Diagenetic losses of organic carbon in oxidized terrestrial paleosols poses major challenges for

108 detection of chemical and isotopic biosignatures preserved within the organic matter fraction. However,

109 this is not the case for all paleosols. Those that originally formed under reducing conditions, such as

110 Permian ( 250 Ma) Histosols (poorly drained organic soils), preserve organic carbon with abundances $>$

11125 wt. \% (Retallack and Krull, 1999), implying that redox state before burial may provide a first-order

112 control on the preservation of organic carbon in ancient soils (Krull and Retallack, 2000).

113 An additional concern for the study of terrestrial paleosol organic matter is that diagenetic

114 alterations ranging from groundwater alteration to precipitation-driven leaching of dissolved organic

115 carbon can result in the addition of exogenous organic molecules, so caution is necessary for interpreting

116 whether the organic fraction has indeed been "preserved" over geological time scales. In other words,

117 terrestrial paleosols can be contaminated by organic molecules that were not original to the soil, thereby

118 complicating efforts to interpret their biosignature preservation potential.

119 One way to constrain the biosignature preservation potential of putative paleosols on Mars is to

120 examine the organic fraction of paleosols from Earth that share compositional and morphological

121 similarities to layered sedimentary rocks on Mars. Examination of oxidized paleosols with Mars-like

122 mineralogy can help determine if low amounts of organic molecules within natural pedogenic mineral

123 matrices can be detected with Mars flight-analog instruments. Furthermore, cosmogenic nuclide dating of

124 these analog paleosols can also identify potential diagenetic additions of organic carbon.

125 This study builds on and combines previous results from an established Mars-analog paleosol

126 sequence (Broz et al., 2021a, 2021b). The focus here is to determine if organic molecules in oxidized

127 paleosols are detectable with Mars flight-analog instrumentation, and to determine if there have been

128 post-depositional additions of exogenous organic carbon. The objectives of this study were a) to

129 determine whether organic carbon in 30-million-year-old Mars-analog paleosols can be detected with

130 thermal and evolved gas analysis, and b) constrain the age of organic carbon using radiocarbon $\left({ }^{14} \mathrm{C}\right)$

131 dating to identify late diagenetic additions of carbon.

132

\subsection{Paleosols at John Day Fossil Beds National Monument in eastern Oregon, USA}

134 Eocene and Oligocene (42-28 Ma) sedimentary rocks at John Day Fossil Beds National

135 Monument in eastern Oregon are a thick sequence of volcaniclastic paleosols which altogether span over

136400 meters of vertical stratigraphy. (Bestland, 1997; Retallack et al., 2000; Horgan et al., 2012; Smith et

137 al., 2018a). The paleosol sequence contains over 500 clay mineral-rich (30-95 wt. \%) paleosols formed

138 over $\sim 15$ Myr through the Eocene-Oligocene boundary (Figure 1) (Retallack et al., 2000; Horgan et al.,

139 2018). Each of the individual profiles formed from pedogenic alteration of andesitic to rhyodacitic

140 volcanic ash and/or tuff, followed by rapid burial via emplacement of an additional layer of tephra onto 
141 the soil surface. This process of soil formation and burial repeated for nearly 15 million years, and as

142 such, the paleosol sequence provides a unique record of Cenozoic climate change in eastern Oregon

143 (Fremd, 1996). Changes in mineralogy throughout the paleosol sequence reflect the Eocene-Oligocene

144 cooling and drying of the climate (Bestland, 2002; Retallack et al., 2004).

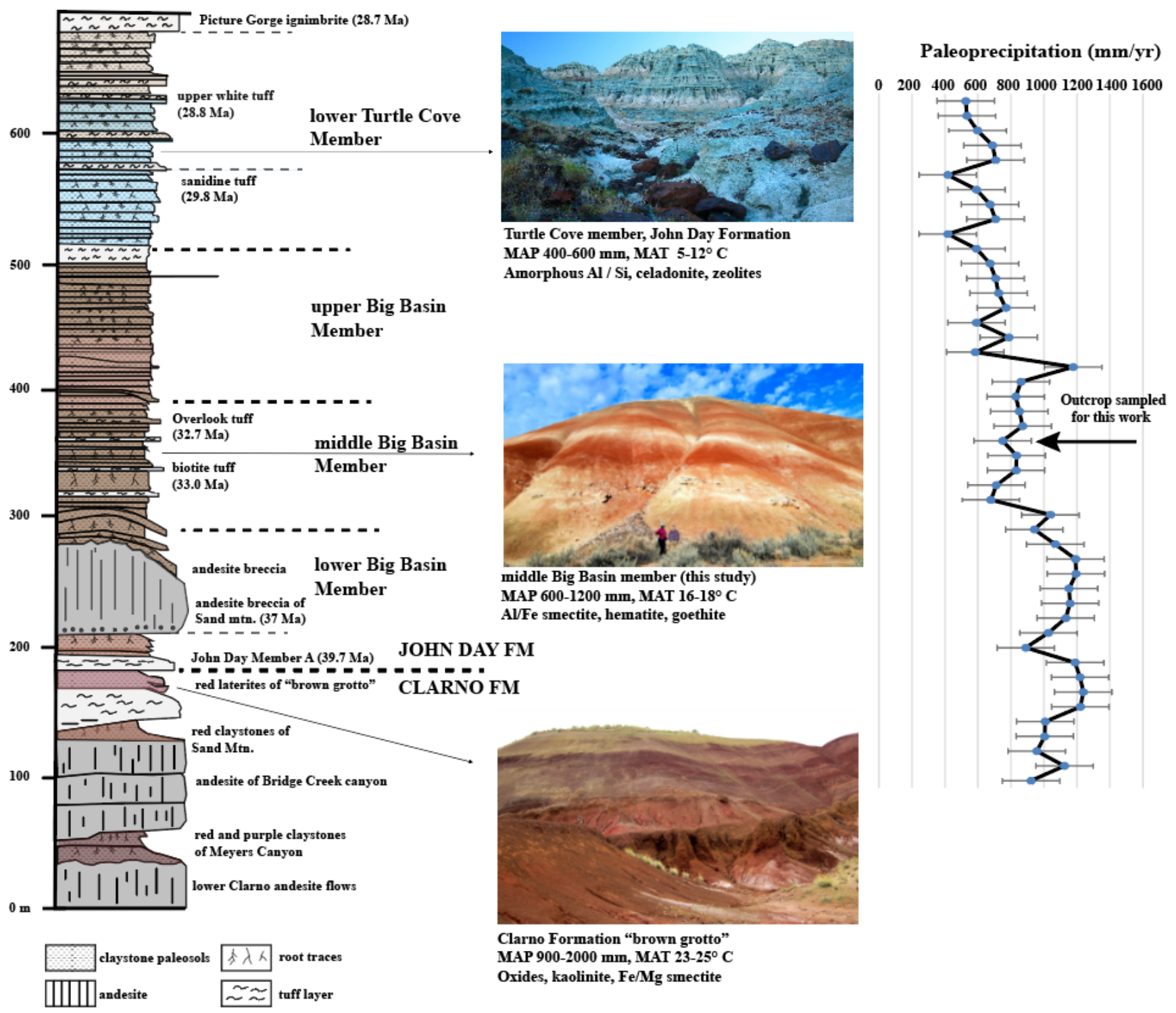

Figure 1. A sequence of Eocene and Oligocene (42-28 Ma) volcaniclastic paleosols in the Clarno and John Day Declining precipitation through the Eocene/Oligocene boundary is inferred from the mineralogy of paleosols from the Clarno and John Day Formations. Paleoprecipitation estimates are from (Sheldon et al., 2015) who used an equation relating molecular weathering ratios (Bases/alumina $\left[\mathrm{CaO}+\mathrm{MgO}+\mathrm{Na}_{2} \mathrm{O}+\mathrm{K}_{2} \mathrm{O} / \mathrm{Al}_{2} \mathrm{O}_{3}\right]$ to mean annual precipitation from a database of modern U.S soils $(\mathrm{r}=0.79$, standard error $=179 \mathrm{~mm})$. The stratigraphic level of 
The Eocene (42-39 Ma) Clarno Formation represents the lowest and oldest unit of the Oregon paleosol sequence. The basal Clarno Formation is characterized by andesite flows interspaced with severely weathered paleosols with accumulations of kaolinite, $\mathrm{Fe} / \mathrm{Mg}$ smectite and oxides (Oxisols and

157 Ultisols in US soil taxonomy) which indicate tropical weathering conditions in the middle to late Eocene 158 (Retallack et al., 2000). A particularly striking exposure of the late Eocene Clarno Formation at the 159 "Brown Grotto" area of the Painted Hills is characterized by thick ( 2-6 meter), repeated profiles of 160 deeply weathered lateritic paleosols (Figure 1, bottom) that are similar to modern soils from Southern 161 Mexico and Central America in climates that are subtropical and humid (Retallack et al., 2000).

162 Stratigraphically above the Clarno Formation, the early Oligocene ( $\sim 33 \mathrm{Ma})$ Big Basin Member of the

163 John Day Formation is characterized by less intensely weathered paleosols (Alfisols and Inceptisols) that 164 are rich in $\mathrm{Al}$ and $\mathrm{Fe}$ smectites such as nontronite and montmorillonite (Figure 1, middle). This middle 165 unit represents a dramatic cooling and drying of the climate through the Eocene-Oligocene boundary. 166 Overlying this unit of the paleosol sequence is the mid-late Oligocene ( $28 \mathrm{Ma})$ Turtle Cove Member of 167 the John Day Formation (Figure 1, top). The brown, green and celadon-colored paleosols of this unit are minimally weathered Aridisols (desert soils) and Andisols (amorphous-rich volcanic soils). Paleosols in this unit are characterized by accumulations of amorphous and nanocrystalline materials (e.g., allophane and imogolite), pedogenic calcite, and diagenetic celadonite (Horgan et al., 2012). There is a dramatic reduction in smectite content and absence of kaolinite which is consistent with weathering under a semi-

172 arid to arid climate regime (Bestland, 2002). Finally, the entire paleosol sequence is capped by 173 approximately 300 vertical meters of flood basalts from the Miocene ( $\sim 16 \mathrm{Ma}$ ) Columbia River Basalt 174 Group. Based on these mineralogical transitions, the Eocene paleosols with accumulations of kaolinite 175 and oxides appear to reflect a subtropical and humid climate, while accumulations of nanophase 176 aluminosilicates and amorphous phases in overlying paleosols indicate stepwise and cooling and drying 177 during the late Oligocene (Retallack et al., 2000).

\subsection{Pedogenic weathering on early Mars and comparisons to terrestrial paleosols}

180 From a global perspective, orbital remote sensing from Observatoire pour la Minéralogie, l'Eau, 181 les Glaces, et l'Activité (OMEGA) and the Compact Reconnaissance Spectrometer at Mars (CRISM)

182 instrument onboard the Mars Reconnaissance Orbiter provide the most compelling evidence of extensive 183 pedogenic-like alteration across the surface of Mars. Potential weathering sequences have been detected 184 in hundreds of locations across Noachian-age terrains, wherever these ancient rocks are not obscured by 185 dust, sand, or overlying strata (Carter et al., 2015; Loizeau et al., 2018). OMEGA and CRISM have 186 collectively gathered visible and near-infrared (VNIR) reflectance spectra of sedimentary deposits at 187 Mawrth Vallis, Oxia Planum, Nili Fossae and other altered Noachian terrains. Some of these deposits, 
such as layered outcrops at Mawrth Vallis, have spectral and stratigraphic similarities to terrestrial

189 paleosol sequences (Horgan et al., 2012, 2018; Hays et al., 2017; Smith et al., 2018b; Poulet et al., 2020).

190 Spectral refinements for CRISM images (e.g., (Viviano-Beck et al., 2014)) are allowing for identification

191 of smaller-scale hydrated mineral deposits at Mawrth Vallis that facilitate a detailed reconstruction of

192 possible geochemical environments on early Mars (Bishop et al., 2020).

\section{Mawrth Vallis}

Previous work identified compositional and morphological similarities between the eastern

196 Oregon paleosol sequence and layered outcrops at Mawrth Vallis (Horgan et al., 2012; Hays et al., 2017;

197 Lantz et al., 2020; Smith and Horgan, 2021). The compositional stratigraphy at Mawrth Vallis has been

198 interpreted as a paleosol sequence (Horgan et al., 2012) or a deep weathering profile (Liu et al., 2021a).

199 Here, a $\sim 200 \mathrm{~m}$ stack of layered sedimentary rocks has spectral signatures consistent with pedogenic-like

200 alteration of mafic sediments(Horgan, 2013). The basal Fe/Mg smectite unit at Mawrth Vallis is

201 dominated by spectral signatures of $\mathrm{Fe} / \mathrm{Mg}$ smectite and is consistent with subaerial alteration under a

202 warm and wet climate (Loizeau et al., 2015; Poulet et al., 2020). This basal unit transitions upward into a

203 thin, ferrous-bearing clay unit that could have resulted from reducing conditions during subaerial

204 weathering. This unit is overlain by layered rocks containing minerals consistent with formation in acidic

205 and evaporitic geochemical settings, inferred from spectral signatures consistent with mixtures of smectite

206 and jarosite (the “doublet' spectral feature) (Noe Dobrea et al., 2016; Danielson et al., 2019; Bishop et al.,

207 2020). Stratigraphically higher, layered rocks with signatures of Al and Fe smectite are consistent with

208 pedogenic weathering of volcaniclastic sediments under a semi-arid climate. Finally, the uppermost layers

209 are characterized by accumulations of poorly consistent aluminosilicates, suggesting minimal or cool-

210 climate alteration, which may represent the terminus of warm and wet conditions on early Mars (Bishop

211 et al., 2020). The entire sequence is then capped by dark-toned sands and/or lava flows. One hypothesis

212 to explain the stratigraphy at Mawrth Vallis is that it may represent the cooling and drying of the Martian

213 climate during the mid to late Noachian (Bishop and Rampe, 2016; Bishop et al., 2020). Similarly, the

214 Oregon paleosol sequence represents a transition from warm and wet conditions. The intensely weathered

215 basal Clarno Formation paleosols transition upward into less-weathered semi-arid paleosols of the middle

216 Big Basin Member, which contains both oxidized (red, brown) and reduced (yellow, black) paleosols.

217 These are subsequently overlain by minimally weathered paleosols of the Oligocene Turtle Cove Member

218 with accumulations of unweathered volcanic glass, amorphous colloids, calcite and hydrated silica which

219 are thought to represent the terminus of warm and wet climate conditions in eastern Oregon. Terrestrial

220 paleosols at the analog site have therefore been considered analogous to dioctahedral clay sequences on

221 Mars. Layered rocks at Mawrth Vallis currently stand as the best example of a putative paleosol sequence 
manuscript submitted to Journal of Geophysical Research: Planets

222 on Mars, but other locations, such as Jezero Crater, also show VNIR spectra consistent with subaerial

223 alteration of mafic sediments.

224

225

226

227

228

229

230

231

232

233

234

235

236

237

238

239

240

241

242

243

244

245

246

247

248

249

250

251

252

253

254

255

\section{Jezero Crater}

Spectral signatures of Al-bearing clay minerals and/or silica deposits that could have formed in subaerial environments were detected approximately $3 \mathrm{~km}$ from the Perseverance rover landing site at Jezero Crater. Across Jezero's western delta and northern fans, there are strong and ubiquitous orbital detections of Al-bearing clay minerals and/or silica that could be either detrital or authigenic in origin (Horgan et al., 2020). The strongest signatures across the western delta are associated with features that resemble point bar deposits and are consistent with formation in subaerial and/or seasonally waterlogged paleoenvironments (Horgan et al., 2020). If authigenic in origin, these deposits could be subaerial paleoenvironments and include individual paleosol profiles. If targeted for in-situ examination by

Perseverance rover, these deposits could provide critical information about the climate and duration of delta activity at Jezero Crater (Horgan et al., 2020). Similarly, terrestrial paleosols examined in this study formed from subaerial weathering of volcaniclastic sediments across alluvial terraces and have accumulated abundant Al clay minerals and amorphous silica (Bestland, 1997; Retallack et al., 2000). The mounting evidence of pedogenic-like processes on Mars emphasizes the need for study of paleosols from Earth to aid in future investigation and interpretation of sedimentary rocks on Mars.

\section{Terrestrial paleosols: Mineralogy and diagenesis}

The present study focuses on three paleosol profiles from the early Oligocene (33 Ma) Big Basin Member of the John Day Formation (Figure 1, middle). A detailed analysis of mineralogy and diagenetic alteration of these samples was previously performed (Broz et al., 2021a). X-ray diffraction evolved gas analysis and visible-near-infrared spectroscopy revealed high abundances ( $>80 \mathrm{wt}$ \%) of montmorillonite and nontronite with lesser amounts of hematite, zeolites, gypsum, and hydrated silica (Tables S4-S6). Diagenetic alterations previously observed in these samples included a) "burial gleization" of near-surface horizons, which is attributed to microbial reduction of $\mathrm{Fe}^{3+}$ in near-surface horizons of paleosols, possibly during anaerobic decay of organic matter; b) dehydration of ferrous oxyhydroxides (goethite) to form fine-grained hematite; c) zeolitization to form clinoptilolite, possibly resulting from diagenetic recrystallization of a poorly crystalline smectite; and d) significant mechanical compaction to approximately $70 \%$ of the original soil thickness (Retallack et al., 2000).

Previously, there was no effort to examine the organic component of these paleosols, and the resulting influence of diagenesis on the organic fraction of Mars-analog paleosols is poorly understood. Examination of terrestrial paleosols with Mars flight-analog instruments such as evolved gas analysis 
manuscript submitted to Journal of Geophysical Research: Planets

allows for a detailed characterization of the organic fraction (discussed below). This can help ascertain if diagenesis has resulted in severe losses of organic carbon in Mars-analog paleosols and determine if organic carbon that remains is detectable with analytical techniques relevant to Mars exploration.

\subsection{Sample Analysis at Mars (SAM) instrument onboard Curiosity Mars Rover}

The overall goal of the SAM instrument was to assess the potential for past habitability by characterizing the martian chemical and isotopic composition of the atmosphere and volatile-bearing surface materials (Mahaffy et al., 2012). The SAM instrument was integral in providing an understanding of organic materials and phases undetectable by CheMin (e.g., amorphous phases, low abundance phases). SAM heats scooped or drilled rock samples from $\sim 30-870^{\circ} \mathrm{C}$ at $35^{\circ} \mathrm{C} \mathrm{min}^{-1}$. Evolved gases produced from the thermal decomposition of volatile-bearing phases were analyzed by a quadrupole mass spectrometer (QMS), gas chromatograph columns for GCMS, or a tunable laser spectrometer (TLS) (Mahaffy et al., 2012). In evolved gas analysis (SAM-EGA) mode, SAM detected bulk gas evolution, whereas in gas chromatography-mass spectroscopy (SAM-GCMS) mode, SAM performed molecular separation and identification of organic molecules (Mahaffy et al., 2012; Eigenbrode et al., 2018). This study focused on SAM-EGA, so SAM-GCMS will not be further discussed. A comprehensive discussion on how organic molecules are detected with SAM- GCMS mode can be found in ${ }^{42}$ and $^{44}$.

Evolved gases and their release temperatures detected by SAM-EGA provide constraints on the mineralogy and organic content of samples in Gale Crater (Archer et al., 2014; Ming et al., 2014; Freissinet et al., 2015; Eigenbrode et al., 2018). The thermal decomposition of solid samples during SAM-EGA occurs during ramped heating, which releases volatile gases including $\mathrm{CO}_{2}, \mathrm{CO}$, hydrocarbons, and organic fragments (i.e., $\mathrm{CH}_{2}, \mathrm{CH}_{3}, \mathrm{C}_{2} \mathrm{H}_{2}$ and others) that are detected by the QMS. The intensity (relative abundance) of volatile release is plotted as a function of the release temperature, generating a time and temperature series of data for each volatile gas release. The volatile release peak temperature during sample decomposition depends on the thermodynamics of the reaction and can be used to constrain the composition of minerals and organic carbon in the sample (Archer et al., 2014), as well as to identify possible associations between minerals and organics (Mcadam et al., 2020b).

Additional future missions to Mars will also employ EGA-like analysis to search for organic molecules. The Mars Organic Molecule Analyzer (MOMA) onboard European Space Agency's ExoMars 2022 Rosalind Franklin rover will use pyrolysis gas chromatography-mass spectrometry (GCMS) and laser desorption spectroscopy to search for biosignatures on Mars. Volatile gases thermally evolved from solid samples in the instrument oven will be separated by the GC and then analyzed individually with the MS (Goesmann et al., 2017) as is the case with SAM-GCMS, though MOMA will combine pyrolysis with laser desorption mass spectrometry, a less destructive technique that allows for identification of large 
intact molecules and polar compounds. The Rosalind Franklin rover will land at Noachian -age (3.9 Ga)

291 Oxia Planum which appears to be a westward extension of the lower parts of the stratigraphy observed at

292 Mawrth Vallis (Ivanov et al., 2020; Loizeau et al., 2020). Like Mawrth Vallis, strong and ubiquitous

293 spectral signatures of dioctahedral Al-rich clay minerals overlying Fe/ Mg clay minerals suggests Oxia

294 Planum may host remnants of a thick ( $200 \mathrm{~m})$ deep weathering profile or paleosol sequence that the

295 rover could encounter during its primary mission.

\subsection{Previous detections of organic carbon with SAM-EGA}

Organic carbon has been detected in sedimentary rocks at Gale Crater with the SAM instrument using both QMS and GCMS (Ming et al., 2014; Rampe et al., 2014; Freissinet et al., 2015; Szopa et al., 2020). Abundances of reduced carbon were very low $(<1 \mathrm{wt}$. \%) and restricted to three samples (Cumberland [CB], Confidence Hills [CH], and Mojave [MJ]). Though all $\mathrm{CO}_{2}$ and $\mathrm{CO}$ detected to date is consistent with oxidized organic compounds, it is possible that contamination by the SAM-GCMS derivatization agent MTBSTFA could have resulted in these peaks. However, high-temperature $\left(>600^{\circ}\right.$ C) $\mathrm{CO}$ releases were consistent with endogenous oxidized martian organics. Additionally, chlorinated hydrocarbons (chlorobenzene [m/z 112], 30 pmol) in the Cumberland drill sample and organo-sulfur compounds including thiophenes and thiols $(\sim 90 \mathrm{nmol})$ in the Mojave and Confidence Hills drill samples were identified in $\sim 3.5$ Ga mudstone, but the sources of these organic molecules was not constrained (Freissinet et al., 2015; Eigenbrode et al., 2018). Observation of dichlorobenzene and trichloromethylpropane in the CB sample at Yellowknife Bay could have been produced by chemical reactions between organic molecules and oxychlorines occurring in the SAM ovens. These chlorinated hydrocarbons could have been derived from organic carbon, either from an endogenous martian source and/or from meteoric infall (Fornaro et al., 2018; Szopa et al., 2020). Though organic carbon has been

\section{4 are not yet fully understood. Recent work has shown that organic salts such as $\mathrm{Ca} / \mathrm{Mg}$ oxalates and/or}

$315 \mathrm{Ca} / \mathrm{Mg}$ acetates may be present in abundances of 1-2 wt. \% in modern eolian sediments (Rocknest

316 sample) as well as in ancient sedimentary rocks at Gale Crater (JK and CB samples) (Lewis et al., 2021).

317 The accumulation of organic salts in eolian deposits suggests they may be a component of regional or

318 global dust on Mars (Lewis et al., 2021).

\subsection{Thermal analysis of organic carbon in modern soils and paleosols}

Thermal analysis techniques similar to SAM-EGA have been employed for understanding the

322 nature and stability of organic matter in modern terrestrial soils, though at present there are only limited

323 studies of paleosols (Noe Dobrea et al., 2016; Smith et al., 2018b). Past work has shown the thermal 
manuscript submitted to Journal of Geophysical Research: Planets

324 decomposition of organic carbon (C) is related to organic carbon composition and particle size in both

325 modern soils (Nelson and Baldock, 2005; Williams et al., 2018) and paleosols (Marin-Spiotta et al.,

326 2014). In modern soils there is an inverse relationship between particle size and proportion of plant

327 biopolymer-derived organic carbon (carbohydrates, lignin) and $\mathrm{C}$ from microbial biomass and/or

328 metabolites (protein, aliphatic C) (Nelson and Baldock, 2005). Larger particle sizes are predominantly

329 associated with labile remains of plant biopolymers, while the clay-size fraction hosts highly recalcitrant

330 (stable) $\mathrm{C}$ compounds which include microbial biomarkers of $\mathrm{n}-\mathrm{C}_{14}$ alkanoic acid (Otto et al., 2005).

331 Organic $\mathrm{C}$ associated with the clay-size fraction thermally decomposes at higher temperatures $(\sim 400-$

$\left.332450^{\circ} \mathrm{C}\right)$ compared to $\mathrm{C}$ associated with larger size fractions $\left(\sim 150^{\circ}-350^{\circ} \mathrm{C}\right)$ (Plante et al., 2011; Marin-

333 Spiotta et al., 2014). Thus, the thermal stability of organic carbon associated with clay minerals and/ or

334 persisting as microaggregates reflects increased resistance to oxidation (Williams et al., 2018) which is

335 one factor among many contributing to stabilization over geological time scales (Bishop et al., 2013).

\subsection{Preservation of organic matter in Archean paleosols}

Life on Earth has a long history with soil, and some of the oldest biosignatures of life on land are

340 found in paleosols (Retallack, 2016; Homann et al., 2018; Finke et al., 2019). Transmission electron

341 microscopy of the clay size fraction of an Archean (2.6 Ga) paleosol from South Africa showed organic

342 carbon in association with surfaces and interlayer spaces of clay minerals, possibly derived from

343 cyanobacterial mats (Watanabe et al., 2000). An Archean ( 2.8 Ga) paleosol from Western Australia

344 contained filamentous, carbon-rich microstructures with regular banding and consistent shape and size

345 (Rye and Holland, 2000). These structures, which contain up to 0.1 wt. \% carbon, have been interpreted

346 as putative microfossils of methanogenic microbial mats living on the soil surface (Rye and Holland,

347 2000). In both Archean paleosol examples, organic carbon was most concentrated in near-surface

348 horizons. Near-surface layers of other Archean paleosols contain additional biosignatures such as

349 isotopically light carbon (Retallack and Noffke, 2019) and sulfur (Nabhan et al., 2016). Early Archean

$350(3.7 \mathrm{Ga})$ metasedimentary deposits from the Isua supercrustal belt in Greenland which have been

351 considered putative paleosols (Retallack and Noffke, 2019) have $\delta^{13} \mathrm{C}_{\text {organic }}$ of -24.2 to $-27.4 \%$ and show

352 mineralogical evidence of subaerial acid-sulfate weathering, including abundant crystals of ripidolite

353 interpreted to be pseudomorphs of the sulfate mineral kieserite. These appear to be grouped into a gypsic

354 (By) horizon within a matrix of bertherine schist. Bertherine, a phyllosilicate in the serpentine group, is

355 thought to have formed from metamorphism of a trioctahedral phyllosilicate like saponite (Retallack and

356 Noffke, 2019), thus implying that early Archean Earth surface weathering may have been comparable to

357 late Noachian surface weathering on Mars. The putative Greenland paleosol has been tortured by 
metamorphism to amphibolite facies and thus any biogenic source for the isotopic fractionation and/or discrimination should be interpreted with caution. In any case, terrestrial paleosols provide compelling evidence of life's ancient relationship with surface environments on Earth, which appears to extend well back into the Archean (Gay and Grandstaff, 1980; Rye and Holland, 2000; Watanabe et al., 2000, 2004; Homann et al., 2018).

Though there appear to be similarities between the modes of weathering on the Early Earth and Mars (e.g., anoxic acid sulfate weathering), the use of Archean paleosols as Mars analogs is complicated by severe diagenetic overprinting that often obscures the original mineralogy and organic content of these ancient land surfaces. Younger, less altered paleosols are more suitable candidates for comparisons with putative paleosols on Mars, yet, as discussed below, these are also imperfect Mars analogs.

\subsection{Limitations of Cenozoic Mars-analog paleosols}

The Eocene-Oligocene (42-28 Ma) eastern Oregon paleosols are an incomplete Mars analog due to several fundamental differences. First, the source of organic carbon within the paleosols is primarily from microbial and/or plant biomass and represents a complex consortium of life above and within the soil profile. Therefore, the organic carbon component of these paleosols and the resulting preservation and degradation mechanisms may not be the same on Mars, but it is possible that putative paleosols at Mawrth Vallis have mineralogy analogous to terrestrial paleosols and thus have a similar mineralogical control on the fate of organic carbon. Nevertheless, the purpose of this study was not to determine the "inputs" of organic carbon in paleosols, but rather to observe the "outcomes" of life on land, e.g., if and how organic carbon is preserved across ancient surface environments.

A principal concern of this work was the assumption that all organic carbon in any lithified paleosol sample was endogenous (e.g., deposited during soil formation) and has subsequently been preserved for $\sim 30$ million years. This assumes no contribution from modern plants or microbes or diagenetic alterations which add exogenous organic carbon. For example, modern soils developing atop paleosol outcrops could have delivered exogenous organics to the underlying paleosols.

Another concern is the suite of common diagenetic alterations which alter paleosols, including zeolitization, illitization and burial decomposition of organic carbon which appear to have affected paleosols examined here to some degree (see Results). However, these are all are assumed to remove endogenous organic carbon (Retallack, 2019), not deliver it. We tested the hypothesis that organic carbon is endogenous to paleosols by radiocarbon dating bulk samples (see Methods).

Large differences in age (Oligocene, [33 Ma] versus Noachian [4.1-3.7 Ga]) also have implications for diagenesis. John Day paleosols have experienced a range of minor to moderate diagenetic 
392 alteration including illitization of smectite, zeolitization and celadonization all resulting from alteration to

393 clinoptilolite facies (Retallack et al., 2000; Horgan, 2016), but it is currently unclear if similar diagenetic

394 alteration has affected potential paleosol sequences on Mars. There are also differences in the oxidation

395 state of the atmosphere during subaerial weathering. The Oregon paleosols formed under a thoroughly

396 oxidizing atmosphere but at present the oxidation state of an early Mars atmosphere is not well

397 constrained (Ramirez et al., 2014). However, leaching of $\mathrm{Fe}^{2+}$ in putative martian paleosols at Mawrth

398 Vallis has been inferred from spectral weathering indices and is consistent with an anoxic, reducing 399 atmosphere during the Noachian (Liu et al., 2021a). Lastly, there are most likely differences in the $\mathrm{pH}$ of

400 fluids participating in hydrolytic weathering of volcaniclastic sediments. The Oregon paleosols formed by

401 pedogenic weathering with circumneutral-pH fluids, but subaerial alteration on Mars could have preceded

402 with acidic, $\mathrm{H}_{2} \mathrm{SO}_{4}$ and $\mathrm{HCl}$-rich surface waters as a result of volcanic outgassing of $\mathrm{H}_{2}$ and $\mathrm{SO}_{2}$ (Liu et

403 al., 2021a, 2021b). Despite these significant differences, the paleosol sequence from eastern Oregon

404 offers a natural example to determine if organic carbon can be detected with thermal and evolved gas

405 analysis techniques similar to SAM-EGA.

\section{Methods}

\subsection{Sample collection}

The paleosols examined in this study were collected from the Painted Hills Unit of the John Day

410 Fossil Beds National Monument in eastern Oregon, USA. A previous study (Broz et al., 2021a)

411 determined the mineralogy and diagenetic alteration of the same set of samples examined in the present

412 study. Samples from three individual paleosols in vertical succession were collected approximately $7 \mathrm{~km}$

413 SW of the entrance to the Painted Hills unit of the John Day Formation (44.631105, -120.213107), in the

414 Middle Big Basin Member of the John Day Formation, approximately $6 \mathrm{~m}$ above the local Eocene-

415 Oligocene boundary (Figure 1, middle). Samples were chosen from this location because they were

416 previously examined for mineralogy and diagenesis, and because ${ }^{40} \mathrm{Ar} /{ }^{39} \mathrm{Ar}$ dating of volcanic tuffs at this

417 stratigraphic level in the section allow for a constrained age of $33.0+/-0.10$ to $32.7+/-0.03 \mathrm{Ma}$ (Biotite

418 Tuff and Overlook Tuff, respectively) (Bestland, 1997). 

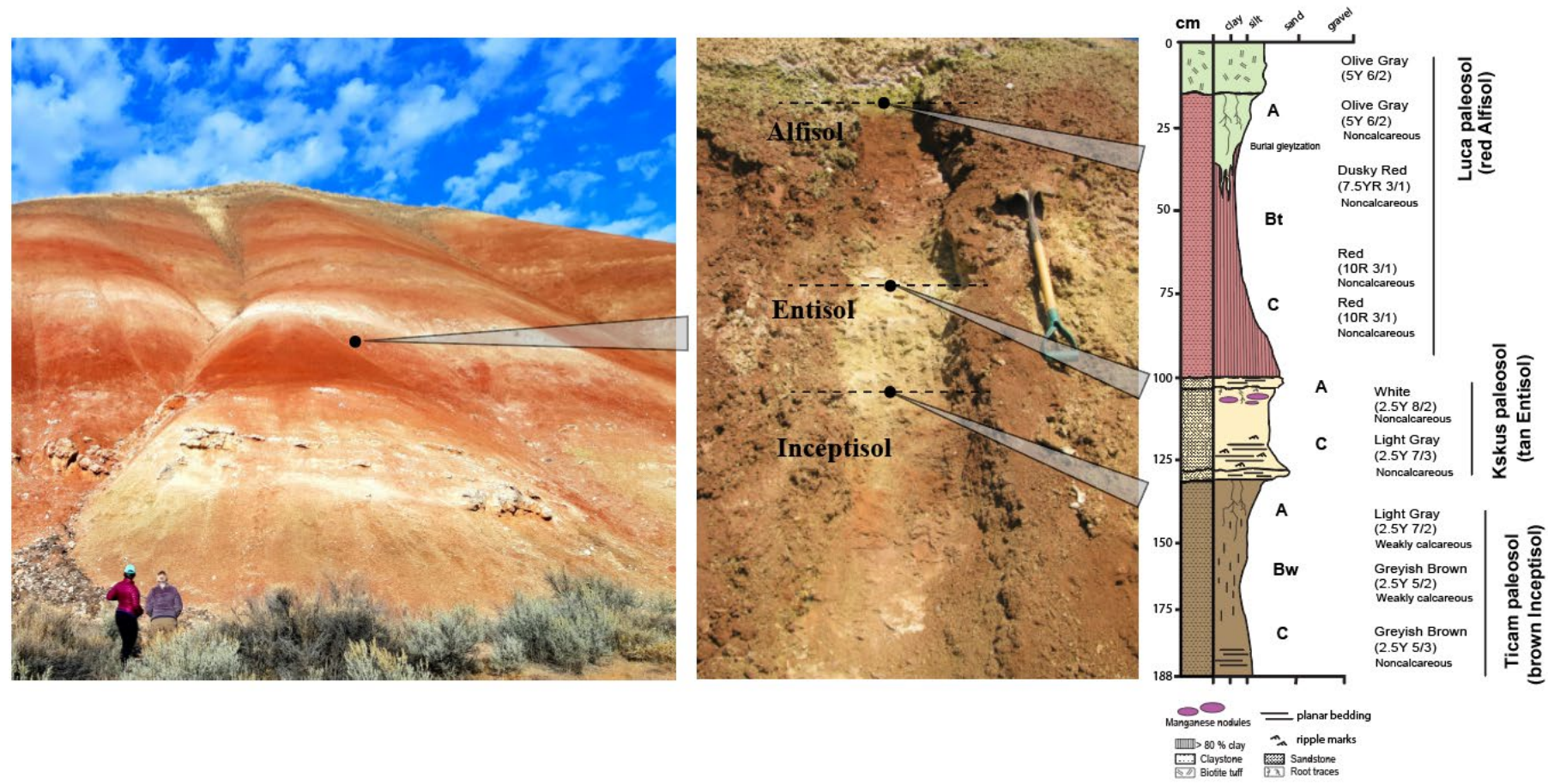

Figure 2. Morphology of three successive paleosols from the early Oligocene (33 Ma) middle Big Basin Member of the John Day Formation in eastern Oregon, USA showing lithology, grain size, horizon designations, and Munsell color. The upper paleosol (red with drab green top) is a moderately weathered red Alfisol (Hapludalf in USDA Taxonomy); stratigraphically below is a minimally weathered and weakly developed Entisol (Fluvent; tan color); the lowest soil (brown color) is an Inceptisol (Andic Eutrochrept, brown color).

To minimize contamination from modern organic carbon during sampling, all loose surface soil and saprolite was removed until the lithified, brick-like unweathered paleosol surface was exposed.

428 Below the saprolite of the thin $(\sim 30 \mathrm{~cm})$ modern soil, all three paleosols were lithified claystone. Sample 429 collection began by trenching with a rock hammer to a $\sim 50 \mathrm{~cm}$ depth into (perpendicular to) the lithified 430 paleosol sequence. Next, a set of samples were gathered down a vertical transect at approximately $10 \mathrm{~cm}$ 431 intervals, similar to sampling the horizons of a modern soil, but with rock hammer. Large $(\sim 1 \mathrm{~kg})$ lithified 432 blocks of claystone were broken out of the outcrop and placed into aluminum foil (ashed at $550^{\circ} \mathrm{C}$ before 433 use) to ensure subsampling for thermal analysis had sufficient volume to expose fresh sample surface

434 (e.g., no weathered surfaces were selected for analysis). Small (5-8 g) subsamples were acquired from the 435 inside of bulk lithified samples with steel chisels that were previously ashed at $550^{\circ} \mathrm{C}$ to remove organic 436 contaminants. These subsamples were then ground to $<0.02 \mathrm{~mm}$ using an agate mortar and pestle (ashed 437 at $550^{\circ} \mathrm{C}$ before use) and stored in glass vials (all ashed at $550^{\circ} \mathrm{C}$ ) prior to thermal analysis and 438 radiocarbon dating. 
No vegetation was present within $\sim 30 \mathrm{~m}$ of the sampled paleosol sequence (Figure 2), likely because the "popcorn" weathering of the smectite-rich modern soil appears to inhibit plant germination and growth. The Munsell color and qualitative calcareousness of samples were described during collection. The three paleosols sampled were a red Alfisol ("Luca" pedotype from (Retallack et al., 2000)), a tan Entisol ("Kskus" pedotype), and a brown Inceptisol ("Ticam” pedotype (Figure 2).

\subsection{Radiocarbon dating of organic carbon in paleosols} paleosols was entirely endogenous (deposited during soil formation) and had been preserved for millions of years, or if there had been additions of exogenous organic carbon to paleosols in the last $\sim 45,000$ years (the method-level detection limit for radiocarbon dating techniques). A radiocarbon age of organic carbon was obtained from four samples, two from the surface and near-surface horizons (A and Bt horizons) of the stratigraphically highest soil (Alfisol) and two from the surface and near-surface horizons of the stratigraphically lowest profile (Inceptisol). All samples for radiocarbon dating were acid-washed to remove inorganic carbonates before radiocarbon dating. For acid washing, ground paleosol samples ( $\sim 5$

$454 \mathrm{~g}$ ) were treated with approximately $20 \mathrm{~mL}$ of $0.1 \mathrm{M} \mathrm{HCl}$ at room temperature for 1 hour, then washed 455 three times with $\sim 30 \mathrm{ml}$ of deionized water and dried at $60^{\circ} \mathrm{C}$ for $24 \mathrm{hr}$. Radiocarbon dating of acid456 washed paleosol samples was performed at the W.M. Keck Carbon Cycle Accelerator Mass Spectrometer 457 at the University of Irvine. The accuracy and precision $(1 \sigma)$ of this analysis on modern carbon $\left(\Delta^{14} \mathrm{C}\right.$ $458>0 \%$ ) was better than $9 \%$. Laboratory blanks yielded a $\Delta{ }^{14} \mathrm{C}$ value of $-996.2 \%$.

\subsection{Thermal and evolved gas analysis of paleosol samples}

The purpose of this work was to use SAM-EGA-like conditions to characterize bulk gas evolution and to measure abundance of organic and inorganic carbon in Mars-analog paleosol samples. A Setaram

462 Labsys Evo differential scanning calorimeter (DSC) / thermal gravimeter (TG) connected to a Pfeiffer

463 Omnistar QMS was configured to operate similarly to the SAM evolved gas analyzer. The SAM

464 instrument does not have TG/DSC capabilities, but these components permit a better understanding of 465 phase transitions and chemical reactions in laboratory experiments. Approximately $50 \mathrm{mg} \pm 3 \mathrm{mg}$ of 466 ground paleosol sample (previously stored in glass vials ashed at $550^{\circ} \mathrm{C}$ to minimize organic 467 contamination) were placed in an $\mathrm{Al}_{2} \mathrm{O}_{3}$ sample crucible (also previously ashed at $550^{\circ} \mathrm{C}$ ). The sample 468 crucible and an identical empty reference crucible were placed in the furnace and then the system was 469 purged twice with helium gas and set to a pressure of 30 mbar. Helium was chosen as a carrier gas 
because it is inert and because it used as a carrier gas in the SAM instrument. The crucibles were heated from approximately $35^{\circ} \mathrm{C}$ to $1000{ }^{\circ} \mathrm{C}$ at a heating rate of $35^{\circ} \mathrm{C} / \mathrm{min}$ and at a flow rate of $10 \mathrm{sccm}$. Volatiles ranging from mass/charge $(\mathrm{m} / \mathrm{z}) 1$ - 100 were measured. All analyses were performed in duplicate.

Total organic carbon (TOC) content was determined using a Netzsch TG/DSC coupled to a Pfeiffer QMS. An $\mathrm{Al}_{2} \mathrm{O}_{3}$ sample crucible and an identical reference crucible were placed in the furnace. The instrument was purged twice with ultra-high purity $\mathrm{O}_{2}$ and set to a pressure of 1000 mbar prior to sample analyses to remove any contamination in the system. Oxygen was chosen as a carrier gas because it encourages complete combustion of all organic and inorganic carbon in samples. The crucibles containing samples were heated from approximately $35^{\circ} \mathrm{C}$ to $1000{ }^{\circ} \mathrm{C}$ at a heating rate of $35^{\circ} \mathrm{C} / \mathrm{min}$ and at a flow rate of $19 \mathrm{ml} \mathrm{O}_{2} / \mathrm{min}$. A series of three blanks were analyzed before and after each group $(\mathrm{n}=10)$ of samples. A calibration curve for $\mathrm{CO}_{2}$ was created by analyzing a calcite standard (Iceland sparry calcite $40 \mathrm{ųM}$ ) at eight sample masses ranging from $0.01-4 \mathrm{mg}$ (Table S1). This calibration curve was used to calculate the amount of $\mathrm{CO}_{2}$ evolved from each sample, and these values were used to calculate total carbon in each sample.

Thermal techniques including TG-DSC-EGA allow for quantitative estimates of organic and inorganic carbon without sample pretreatment, in part due to the large differences in thermodynamics and peak $\mathrm{CO}_{2}$ release temperatures. By contrast, TOC determinations via elemental analysis involve an acid pretreatment step to remove carbonates. Paleosol samples were not acid-pretreated for thermal and evolved gas analyses because some organic carbon can be oxidized during acid-washing (e.g., Apesteguia et al., 2018). In the present study, carbon was considered organic between $150-550^{\circ} \mathrm{C}$ and inorganic from $\sim 700-900^{\circ} \mathrm{C}$. Total organic carbon was quantified by deconvolving $\mathrm{CO}_{2}$ peaks if a carbonate-C peak was present. This was done by determining the relative percentage of peak area from inorganic carbonevolved $\mathrm{CO}_{2}\left(\sim 700-900^{\circ} \mathrm{C}\right)$ then subtracting this value from total carbon-evolved $\mathrm{CO}_{2}$ peak area to solve for TOC. All evolved gas plots were background-corrected to account for possible atmospheric contamination.

\section{Results/Discussion}

\subsection{Radiocarbon dating of paleosol organic carbon}

Radiocarbon dating of four samples from two different paleosol profiles showed ages between $6265 \pm$ 25 years BP and $14560 \pm 170$ years BP (Table 1). These samples all showed a distinct signature of exogenous organic carbon because the samples were not radiocarbon dead $\left({ }^{14} \mathrm{C}-\right.$ free $)$. 
Table 1. Total organic carbon (TOC), total inorganic carbon (TIC) and radiocarbon dating of paleosols examined in this stud

\begin{tabular}{|c|c|c|c|c|c|c|c|c|c|c|c|}
\hline Paleosol & $\begin{array}{l}\text { Pedotype } \\
\vdots\end{array}$ & $\begin{array}{l}\text { Horizon } \\
\varphi\end{array}$ & $\begin{array}{l}\text { Depth in } \\
\text { profile (cm) }\end{array}$ & $\begin{array}{l}\text { Total C (wt. } \\
\%)\end{array}$ & $\begin{array}{l}\text { TOC } \\
\text { (wt. \%) }{ }^{\dagger}\end{array}$ & $\begin{array}{l} \pm \sigma \\
\text { TOC } \S \\
\end{array}$ & $\begin{array}{l}\text { TIC } \\
\text { (wt. \%) }\end{array}$ & $\begin{array}{l}\text { Expected } \\
\text { Age }\end{array}$ & $\Delta^{14} C^{\alpha}$ & $\pm \Delta^{14} \mathrm{C}$ & $\begin{array}{l}{ }^{14} \mathrm{C} \text { age } \\
(\mathrm{BP})^{\dagger}\end{array}$ \\
\hline Alfisol & Luca & A & 4 & 0.073 & 0.031 & 0.0062 & 0.042 & $\sim 33 \mathrm{Ma}$ & $\begin{array}{c}- \\
543.07\end{array}$ & 3.85 & 6265 \\
\hline Alfisol & Luca & A & 14 & 0.094 & 0.026 & 0.0097 & 0.068 & & & & \\
\hline Alfisol & Luca & $\mathrm{Bt}_{1}$ & 46 & 0.021 & 0.018 & 0.0016 & 0.003 & $\sim 33 \mathrm{Ma}$ & 838.12 & 3.37 & 14560 \\
\hline Alfisol & Luca & $\mathrm{Bt}_{2}$ & 63 & 0.067 & $\mathrm{ND}^{\mho}$ & - & 0.067 & & & & \\
\hline Alfisol & Luca & $\mathrm{C}$ & 88 & 0.033 & 0.002 & 0.007 & 0.031 & & & & \\
\hline Entisol & Kskus & A & 100 & 0.046 & 0.021 & 0.0068 & 0.024 & & & & \\
\hline Entisol & Kskus & $\mathrm{C}$ & 120 & 0.036 & 0.013 & 0.0037 & 0.024 & & & & \\
\hline Inceptisol & Ticam & A & 125 & 0.024 & 0.018 & 0.007 & 0.006 & $\sim 33 \mathrm{Ma}$ & -567.1 & 1.83 & 6655 \\
\hline Inceptisol & Ticam & $\mathrm{Bw}_{1}$ & 131 & 0.027 & 0.008 & 0.0013 & 0.019 & & & & \\
\hline Inceptisol & Ticam & $\mathrm{Bw}_{2}$ & 160 & 0.020 & 0.011 & 0.0023 & 0.010 & $\sim 33 \mathrm{Ma}$ & -545.4 & 1.33 & 6220 \\
\hline Inceptisol & Ticam & $\mathrm{C}$ & 175 & 0.026 & 0.001 & 0.0013 & 0.026 & & & & \\
\hline
\end{tabular}

$\dagger$ Determined by thermal analysis (TG-DSC-EGA) without acid pre-treatment of samples; average of two

duplicates. To encourage complete combustion of organic phases in samples, oxygen was used as a carrier gas

for determination of total C, TIC and TOC.

$\$$ Pedotypes (soil orders) are from Retallack et al. 2000

$\varphi$ Horizons follow USDA Soil Survey Staff (2014) major horizon designations

${ }^{\mho} \mathrm{ND}=$ No detection; below limit of quantification

$\S$ Standard error for TOC determination from duplicate analysis

${ }^{\alpha}$ Radiocarbon concentrations are given as fractions of the modern standard $(\mathrm{fM}), \Delta^{14} \mathrm{C}$, and conventional radiocarbon age.

502

503 The occurrence of Holocene-age organic matter in paleosol samples was consistent with

504 diagenetic inputs of organic carbon. There are several possibilities to explain the accumulation of ${ }^{14} \mathrm{C}$ in

505 the organic fraction of samples. First, a diagenetic event that occurred between $\sim 6$ and $\sim 14$ Ka BP could

506 have delivered exogenous organics into the underlying paleosols, perhaps during exhumation to the

507 surface and /or leaching of organic acids from surface biota during that time. Cosmogenic exposure dating

508 such as ${ }^{10} \mathrm{Be}$ surface exposure dating would provide important evidence to constrain the exhumation

509 history of the paleosols examined here (Balco et al., 2005; Schiller et al., 2009). However, there was no

510 sedimentological evidence of exhumation and re-burial of any of the three paleosols at the field site, so

511 other possibilities to explain the radiocarbon dates were explored.

512 Another possible source of exogenous organic carbon was from precipitation-driven leaching of

513 dissolved organic carbon from modern biota living in the current weathering zone above the paleosol

514 outcrop. The fraction of modern carbon (fM) across four samples ranged from $0.469 \pm 0.039$ to $0.1633 \pm$

5150.034 (Table 1) and was highest in the surface (A horizon, $14 \mathrm{~cm}$ ) of the Alfisol and lowest in the

516 subsurface (Bt horizon, $46 \mathrm{~cm}$ ), suggesting this paleosol contained a mixture of ancient and modern

517 organic carbon, the latter possibly delivered via precipitation-driven leaching. As such, it is possible that

518 small amounts of exogenous modern organic carbon from the weathered zone above paleosol outcrops

519 have mixed with larger amounts of ${ }^{14} \mathrm{C}$-free organic carbon endogenous to paleosols. In this way, a

520 radiocarbon date of $\sim 6-14 \mathrm{Ka} \mathrm{BP}$ could represent a mixing of recent/modern organic carbon and $\sim 33 \mathrm{Ma}$ 
521 organic carbon. This hypothesis is supported by the erosion rate for the site, which was previously

522 determined to be $4.94 \pm 0.05 \mathrm{~mm} / \mathrm{yr}$. (Sweeney et al., 2015). Using this erosion rate, the $20 \mathrm{~cm}$-thick soils

523 that formed on top of the paleosols are only about 40 years old and could have leached modern organics

524 into the underlying paleosols during this time.

525 There was also a weak relationship between the radiocarbon age and the depth into the outcrop

526 where the sample was collected (Table 1). Younger radiocarbon dates were observed in shallower

527 samples taken closer to the modern weathering zone. However, a decrease in ${ }^{14} \mathrm{C}$ content with depth is

528 commonly observed in modern soils because subsurface horizons preferentially accumulate older,

529 refractory organic carbon primarily via sorption to surfaces of minerals and amorphous phases (Lawrence

530 et al., 2021). Across four paleosol samples in this work, the radiocarbon age generally increased with

531 depth, suggesting there may be age-depth relationship for samples (Table 1), but this result should be

532 interpreted with caution because only four samples were dated in this work, and because age-depth trends

533 are routinely observed in modern soils (Ewing et al., 2008). In any case, there may be a sampling depth

534 (i.e., $>1$ meter) that significantly reduces or eliminates exogenous carbon additions to paleosols. These

535 demonstrate that radiocarbon dating can be a useful technique for constraining the age of organic carbon

536 in ancient terrestrial surface environments.

\subsection{Thermal and Evolved Gas Analysis}

\subsection{1 $\mathrm{CO}_{2}$ and $\mathrm{CO}$ evolutions}

When subject to thermal and evolved gas analysis, all samples evolved $\mathrm{CO}_{2}$ at temperatures ranging from $\sim 150-800^{\circ} \mathrm{C}$ and had two distinctive $\mathrm{CO}_{2}$ peaks (Figure 3). A broad low temperature $\sim 200$

$542-500^{\circ} \mathrm{C}$ peak was followed by a sharp high-temperature peak at $\sim 650-750^{\circ} \mathrm{C}$ which was observed in all 543 samples. $\mathrm{CO}_{2}$ evolved at $150-500^{\circ} \mathrm{C}$ is primarily from organic carbon decomposition (Sutter et al., 2017;

544 Apesteguia et al., 2018) but also possible are contributions are from $\mathrm{CO}_{2}$ inclusions in minerals or 545 amorphous phases, or from adsorbed atmospheric $\mathrm{CO}_{2}$ (Ming et al., 2014). The organic $\mathrm{C}$ contributing to 546 evolved $\mathrm{CO}_{2}$ is most likely from simple organic compounds $\left(<350^{\circ} \mathrm{C}\right)$ or refractory macromolecular 547 organic compounds $\left(300-600^{\circ} \mathrm{C}\right)$ (Eigenbrode et al., 2018). 


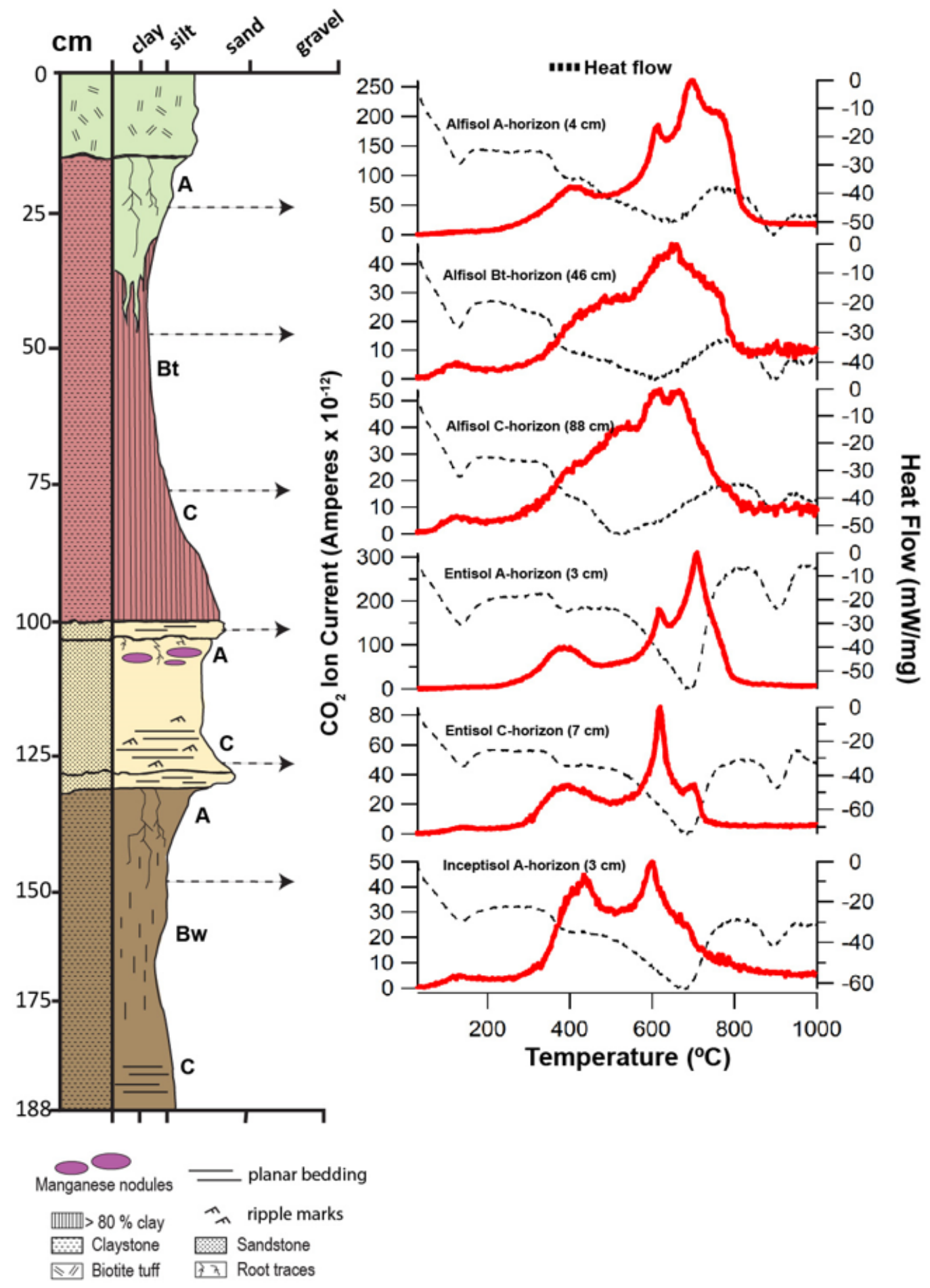

Figure 3. Evolutions of $\mathrm{CO}_{2}$ (red traces) and heat flow (dashed traces) from early Oligocene (33 $\left.\mathrm{Ma}\right) \mathrm{Al} / \mathrm{Fe}$ smectite-rich paleosols from the John Day Fossil Beds National Monument, Oregon. Red trace is $\mathrm{CO}_{2}(\mathrm{~m} / \mathrm{z} 44)$ and dashed trace is heat flow from differential scanning calorimetry (DSC). Helium was used as a carrier gas for all analyses. 
The endothermic thermal decomposition of $\mathrm{Ca}$ carbonate was a probable source of $\mathrm{CO}_{2}$ release from approximately $550-800^{\circ} \mathrm{C}$ (Cannon et al., 2012; Sutter et al., 2012). High temperature $\left(>650^{\circ} \mathrm{C}\right)$ $\mathrm{CO}_{2}$ evolutions generally exceeded the low temperature $\left(150-550^{\circ} \mathrm{C}\right) \mathrm{CO}_{2}$ evolutions in peak area across all samples, though both high temperature and low temperature $\mathrm{CO}_{2}$ evolutions were on the same order of magnitude. Total inorganic carbon (TIC) values varied from 0.006 to $0.068 \mathrm{wt}$. \% (Table 1 ) and the ratio of inorganic carbon to total carbon ranged from 0.14 to 1 , consistent with variable mixtures of $\mathrm{Ca}$ carbonate and organic carbon in each sample. There are well-defined Ca carbonate endotherms in the heat flow data from the Entisol and Inceptisol, but this trend was not so well-defined in the Alfisol (Figure 3) and there also appears to be "doublet" high-temperature $\mathrm{CO}_{2}$ peaks for the Entisol, suggesting a combination of $\mathrm{Ca}$-carbonate and perhaps dolomite or ankerite, though these phases were not previously observed with XRD (Table S6). DSC-EGA analysis of modern soils containing various amounts of calcite have a similar sharp endothermic $\mathrm{CO}_{2}$ peak release temperature at $\sim 700^{\circ} \mathrm{C}$ which was attributed to the thermal decomposition of $\mathrm{Ca}$ carbonate (Apesteguia et al., 2018). An additional $\sim 900^{\circ} \mathrm{C}$ endotherm observed in all samples was unrelated to carbonate decomposition and instead was attributed to thermal decomposition of sulfate minerals such as jarosite, which was previously detected in trace amounts with $\mathrm{x}$-ray diffraction (Table S6). Interestingly, Ca-carbonate was not previously identified from x-ray diffraction patterns (Table S6 and Figure S3), and thus it is likely that these samples contain inorganic carbonate below detection limit of XRD ( 1 wt. \%), but not SAM-EGA (0.01 wt. \%). This agrees with estimated abundances of TIC which were below $1 \mathrm{wt}$. \% (Table 1) and demonstrates the ability of SAMEGA-like analyses to detect trace amounts of inorganic carbon in complex pedogenic mineral matrices. organic compounds in refractory or thermally mature organic matter which occur over a broad range of temperatures $\left(150-800^{\circ} \mathrm{C}\right)$. Previous investigation showed no coalification of organic matter or development of secondary porosity in any paleosols from the Painted Hills, which were buried by an estimated 1.5 - 2 km of overburden (Retallack et al., 2000; Horgan, 2016), suggesting paleosol samples here contain refractory but not thermally mature organic compounds. the highest total organic carbon detected ( $\sim 0.03$ wt. \%, surface horizon of Alfisol) evolved a $\mathrm{CO}_{2}$ release peak at $\sim 400{ }^{\circ} \mathrm{C}$ that co-occurred with the release of $\mathrm{CO}$. This trend of coevolved $\mathrm{CO}$ and $\mathrm{CO}_{2}$ at $\sim 400^{\circ} \mathrm{C}$ was observed across all paleosol samples. Evolution of CO was consistent with incomplete combustion of organics and/ or the presence of oxygen-bearing organics (Sutter et al., 2017). The co-occurrence of CO and $\mathrm{CO}_{2}$ was not observed at high $\left(\sim 700^{\circ} \mathrm{C}\right)$ temperatures (Figure 4$)$ because the thermal decomposition 
of Ca carbonate does not produce $\mathrm{CO}$. Thus, evolved $\mathrm{CO}$ detections near $400^{\circ} \mathrm{C}$ were consistent with the

589 decomposition of organic compounds.

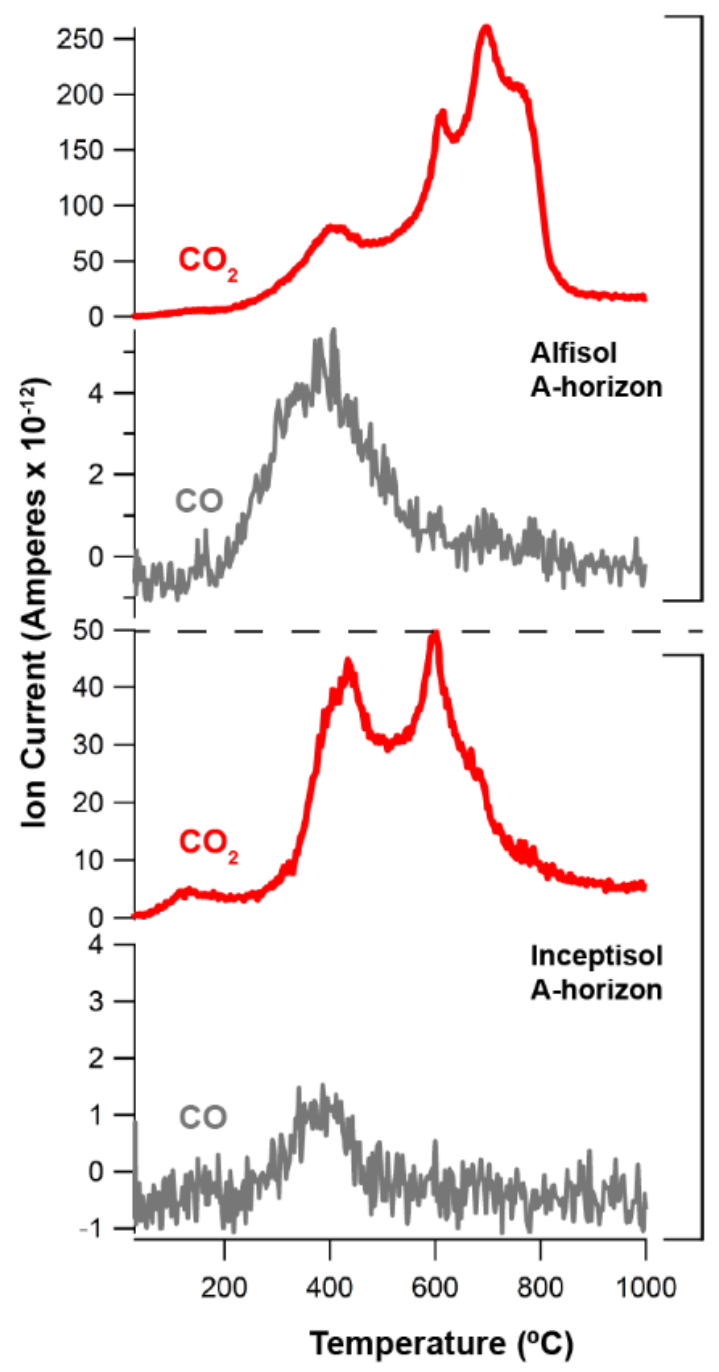

Figure 4. $\mathrm{CO}_{2}$ (red trace) and $\mathrm{CO}(\mathrm{m} / \mathrm{z} 28)$ (grey trace) evolutions from the surface horizons of paleosols at the John Day Fossil Beds National Monument, Oregon. Top panel is surface $(4 \mathrm{~cm})$ horizon of an Alfisol; bottom panel is surface $(3 \mathrm{~cm})$ horizon of an Inceptisol.

\subsubsection{NO evolutions}

Nitric oxide (NO; m/z 30) was detected in all paleosol samples (Figure 5) and was consistent with

599 (Alfisol A-horizon), evolutions of NO start at $\sim 300^{\circ} \mathrm{C}$ and show peak release temperature of $\sim 400^{\circ} \mathrm{C}$

600 and a shoulder at $\sim 600^{\circ} \mathrm{C}$ (Figure 5). Additionally, organic fragments observed in this sample included

$601 \mathrm{CH}_{2}(\mathrm{~m} / \mathrm{z} 14), \mathrm{CH}_{3}\left(\mathrm{~m} / \mathrm{z}\right.$ 15), and $\mathrm{C}_{2} \mathrm{H}_{2}(\mathrm{~m} / \mathrm{z} 26)$ (Figure 6). Evolutions of $\mathrm{NO}$ were simultaneous with 
602 evolutions of these organic fragments at $\sim 400^{\circ} \mathrm{C}$, suggesting the oxidation of a nitrogen-bearing organic 603 compound was a significant contributor to evolved NO (Stern et al., 2015).

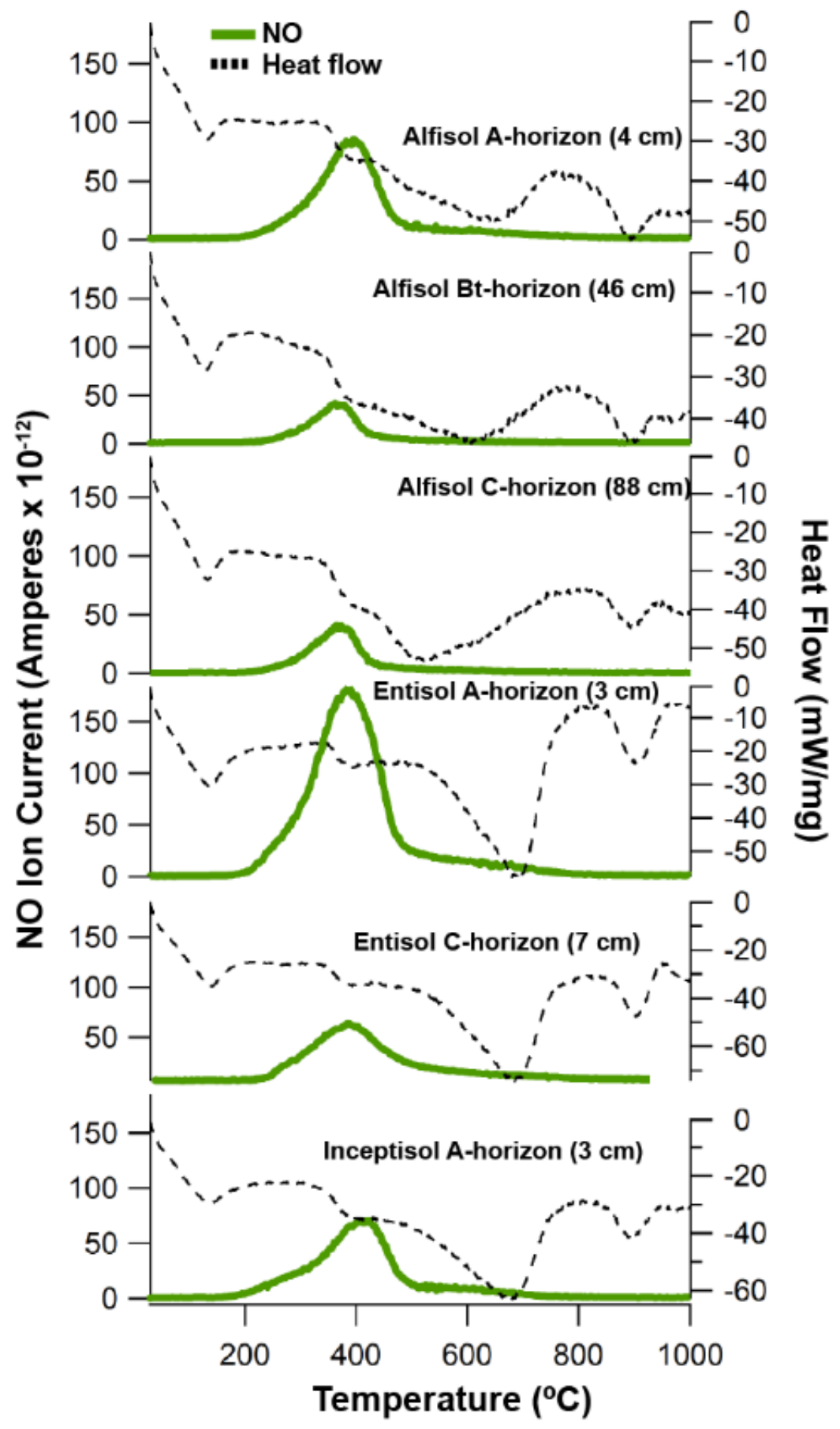


The thermal decomposition of nitrates can also release NO, though at elevated temperatures ( $>$ $500^{\circ} \mathrm{C}$ ) relative to nitrogenated organics (Stern et al., 2015), and therefore the release peak temperate of

610 NO release can constrain the source of NO. For example Alkali $(\mathrm{Na}, \mathrm{K})$ and alkaline earth $(\mathrm{Mg}, \mathrm{Ca})$ metal 611 nitrates decompose to $\mathrm{NO}$ at temperatures $>560^{\circ} \mathrm{C}$ (Stern et al., 2015). In laboratory experiments under 612 SAM-like conditions, $\mathrm{Fe}\left(\mathrm{NO}_{3}\right)_{3}$ begins to decompose to $\mathrm{NO}$ at $<200^{\circ} \mathrm{C}$ and exhibits two distinct 613 releases of $\mathrm{NO}$ at $\sim 300$ and $\sim 450^{\circ} \mathrm{C}$, which has been attributed to dehydration and hydrolysis of $614 \mathrm{Fe}\left(\mathrm{NO}_{3}\right)_{3}$, respectively (Stern et al., 2015). Instead, $\mathrm{NO}$ release in paleosol samples began at $\sim 250^{\circ} \mathrm{C}$ and 615 exhibited a single peak at $\sim 400^{\circ} \mathrm{C}$ across all samples (Figure 5), unlike the dual high-temperature NO 616 peaks from decomposition of $\mathrm{Fe}\left(\mathrm{NO}_{3}\right)_{3}$. The simultaneous evolution of $\mathrm{NO}, \mathrm{CO}_{2}$, and organic fragments in paleosol samples analyzed here (Figure 6) are an additional line of evidence suggesting NO releases could have resulted from oxidation and/or decarboxylation of nitrogen-bearing organic compounds.
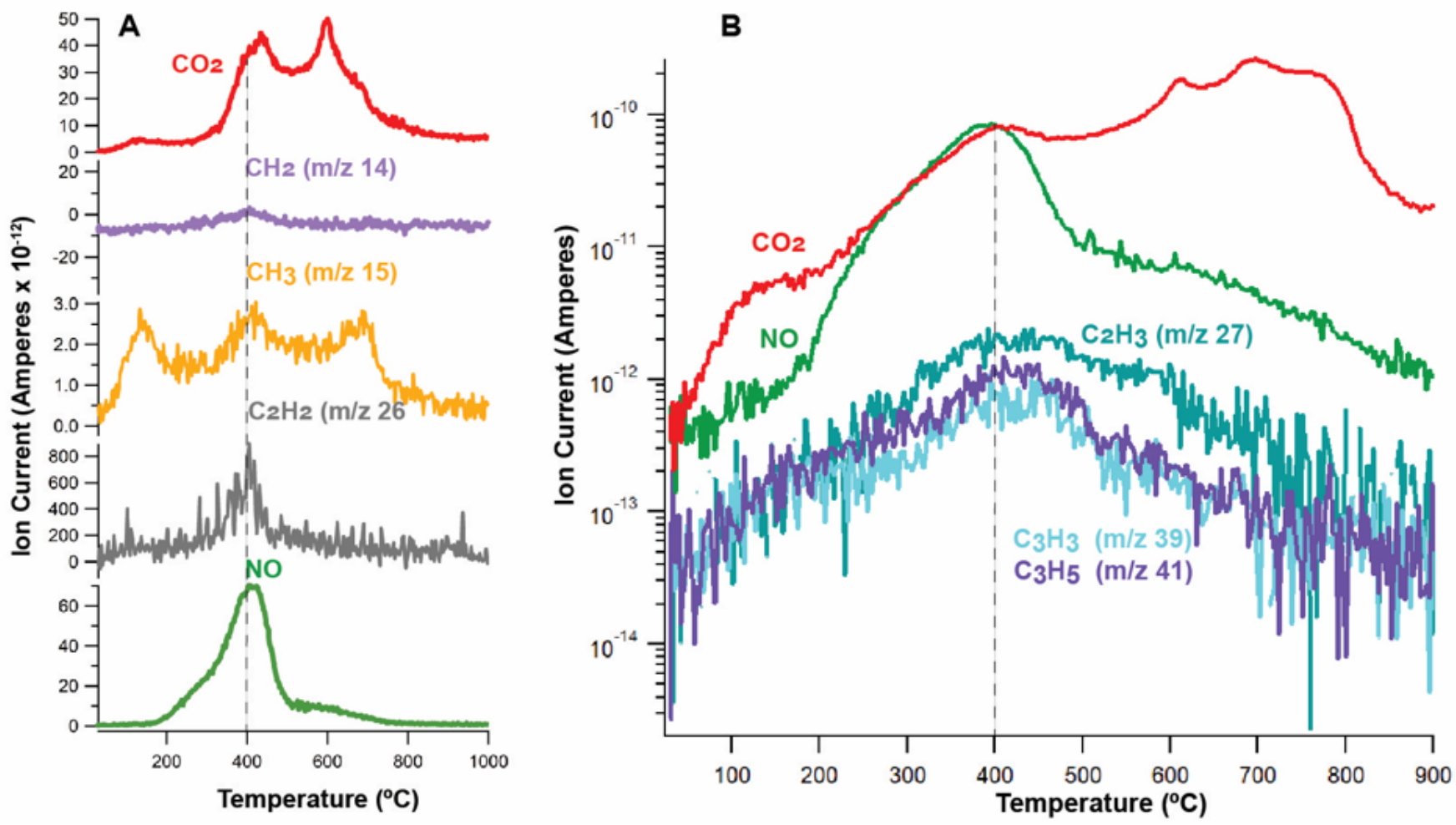

Figure 6. Simultaneous evolutions of $\mathrm{CO}_{2}, \mathrm{NO}(\mathrm{m} / \mathrm{z} 30)$ and organic fragments in paleosol surface horizons. (A) Evolutions of $\mathrm{CO}_{2}, \mathrm{NO}(\mathrm{m} / \mathrm{z} 30)$, and organic fragments $(\mathrm{m} / \mathrm{z} 14,15,26)$ from the surface horizon of the Inceptisol $(3 \mathrm{~cm})$. (B) Semi-log scale plot of $\mathrm{CO}_{2}, \mathrm{NO}$ and additional organic fragments $(\mathrm{m} / \mathrm{z} 27,39,41)$ from the surface horizon $(4 \mathrm{~cm})$ of the Alfisol

One possible source of nitrogen-bearing organic carbon compounds is pyrogenic carbon (char) in paleosol samples that formed as a result of wildfires across the original soil landscape (Kurth et al., 2006). Nitrogen-bearing organic compounds such as nitriles, pyridine and pyrrole-derive compounds have been 
629 observed with pyrolysis GC/MS in modern fire-affected soils (De la Rosa et al., 2008). These modern

630 soils were also observed to have a broad $\sim 400^{\circ} \mathrm{C}$ peak release temperature of $\mathrm{NO}(\mathrm{m} / \mathrm{z} 30)$ during TG-

631 DSC-EGA, suggesting that pyrogenic carbon may be the source of low-temperature NO release in soils.

632 However, the fire history of paleosols in the present study has not yet been investigated. Although it is

633 impossible to determine the original inputs of nitrogen-bearing organics in paleosols, nitrogen may have

634 been incorporated into increasingly stable organic matter as a consequence of forest fires, and may persist

635 in paleosols today as char. Previous authors have reported the occurrence of preserved char in paleosols

636 of late Permian(Miller et al., 1996) and late Jurassic age(Matthewman et al., 2012) paleosols,

637 respectively, so it is plausible that nitrogen-bearing char may be responsible for the overlapping $\sim 400^{\circ} \mathrm{C}$

$638 \mathrm{NO}$ and $\mathrm{CO}_{2}$ peaks observed here.

\subsection{Possible mechanisms of organic carbon preservation in paleosols}

We observed evolutions of volatile gases from clay-rich paleosols that may have resulted from the preservation of organic carbon over geological time scales. The fragmentation of organic molecules during pyrolysis EGA provides limited constraints on the types of molecules present, but it can help determine if there are any associations between minerals and organic molecules. These associations can include physical occlusion, chemisorption and/or adsorption to mineral surfaces, or intercalation in clay minerals (Kleber et al., 2005, 2021; Schmidt et al., 2011; François et al., 2015). A strong correlation between the peak release temperature of organic fragments and the release of $\mathrm{H}_{2} \mathrm{O}$ or other volatiles would suggest that organic matter could have been associated with minerals.

One line of evidence that organic molecules may have persisted in association with clay minerals is co-occurring evolutions of organic fragments, $\mathrm{CO}_{2}$, and water releases from clay dehydroxylation. Alsmectite in the surface horizon of the Alfisol began dehydroxylating at $\sim 400^{\circ} \mathrm{C}$ (broad $\mathrm{H}_{2} \mathrm{O}$ peak) which co-occurred with evolutions of $\mathrm{CO}_{2}$ and organic fragments (Figure 7). This sample had the highest TOC ( $\sim 0.03$ wt. $\%$, Table 1 ), a radiocarbon date of $\sim 6300$ years BP and a phyllosilicate content of $\sim 85$ wt. \%

654 (Table S1). The high clay mineral content could be related to the abundance of organic carbon in this

655 sample. Many of the deeper samples had higher temperatures of clay dehydroxylation due to differences

656 in clay mineralogy and/or abundance, such as the Entisol and Alfisol (Figure S1). These samples were

657 depleted in organic carbon (Table 1) relative to the Al smectite-rich surface horizon of the Alfisol.

658 Additional investigations such as microscale imaging (e.g., transmission electron microscopy) and

659 methods to characterize the bonding environments between minerals and organics in paleosols are needed 660 to support this interpretation. 


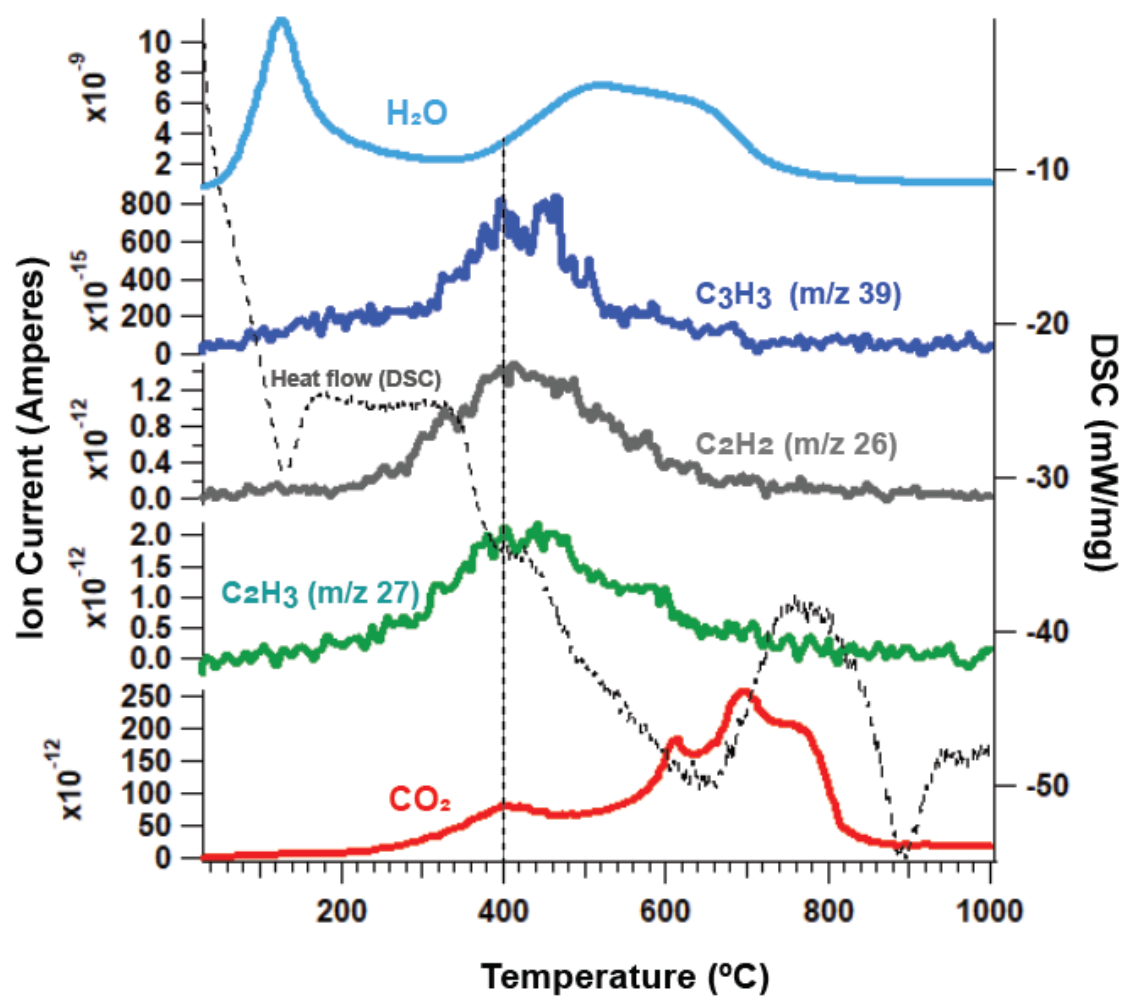

Figure 7. Evolutions of $\mathrm{CO}_{2}$, organic fragments, and $\mathrm{H}_{2} \mathrm{O}$ from the surface horizon of the Alfisol $(4 \mathrm{~cm})$. Cooccurring releases of $\mathrm{CO}_{2}$ and organic fragments at the onset of Al-smectite dehydroxylation $\left(\mathrm{H}_{2} \mathrm{O}\right.$ release at $\sim 400^{\circ}$ $\mathrm{C}$, vertical dotted line) suggest organic molecules may have been associated with clay minerals. Dashed trace is heat flow from differential scanning calorimetry (DSC).

It is important to note that there are many competing factors that control the preservation and degradation of organic carbon in terrestrial environments. Minerals themselves may facilitate oxidation of organic carbon compounds (Kleber et al., 2021), as is the case with certain Mn-bearing minerals (Reardon et al., 2016). Paleosols examined here contained between $\sim 70-90$ wt. \% smectite, primarily as mixtures of montmorillonite and nontronite (Tables S4 and S6). Possible mechanisms of organic carbon preservation include the formation of organo-mineral complexes, and/or the formation of microaggregates which may have increased the biochemical stability of organic molecules, as observed in modern soils (Plante et al., 2011) and Quaternary paleosols (Marin-Spiotta et al., 2014). Smectite clay minerals in particular preserve organic molecules due to their high specific surface area, negatively charged interlayers, and cations which inhibit water flow, thus making them favorable locations for the preservation of organic carbon over millions or possibly billions of years (Bishop et al., 2013; Noe Dobrea et al., 2016; Szopa et al., 2020).

Interactions with sulfur can also aid in the preservation of organic molecules in soils and sediments over geological time scales (Matthewman et al., 2012; François et al., 2015; Eigenbrode et al., 2018; Alekseeva et al., 2019). The incorporation of organic C into the crystal lattice of sulfate minerals 
683

684

685

686

687

688

can increase thermodynamic stability and therefore increase the temperature of organic carbon decomposition during EGA (François et al., 2015). Minor detections of jarosite and gypsum in XRD patterns $(<5$ wt. $\%)$ were observed, and these minerals could have also contributed to the preservation of organics (Tables $\mathrm{S} 5$ and $\mathrm{S} 6$ ). Minor $\mathrm{SO}_{2}$ evolutions at $\sim 800^{\circ} \mathrm{C}$ across all samples (Figure $\mathrm{S} 1$ ) were consistent with the decomposition of sulfate minerals. A single sample (Entisol $7 \mathrm{~cm}$ ) had a lowtemperature $\mathrm{SO}_{2}$ peak that co-occurred with the $\mathrm{CO}_{2}$ release at $\sim 400^{\circ} \mathrm{C}$ (Figure 8).

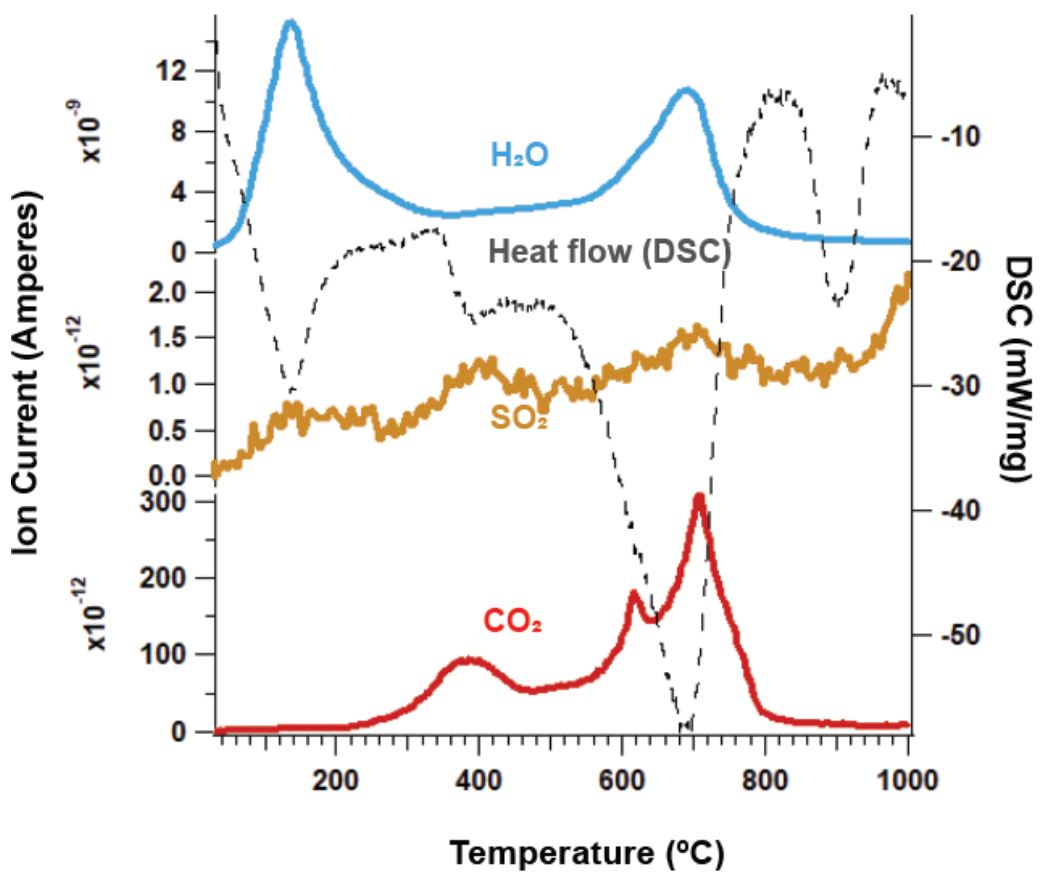

Figure 8. Evolutions of $\mathrm{H}_{2} \mathrm{O}$ (blue trace), $\mathrm{SO}_{2}$ (yellow trace), $\mathrm{CO}_{2}$ (red trace), and heat flow (dashed trace) from the surface horizon of the Entisol $(3 \mathbf{~ c m})$. DSC - differential scanning calorimetry (heat flow), $\mathrm{H}_{2} \mathrm{O}-\mathrm{m} / \mathrm{z}$ $18, \mathrm{SO}_{2}-\mathrm{m} / \mathrm{z} 64, \mathrm{CO}_{2}-\mathrm{m} / \mathrm{z} 44$.

Trace amounts of $\mathrm{Mg}$ sulfates in the Alfisol could account for minor $\mathrm{SO}_{2}$ releases $>700^{\circ} \mathrm{C}$ including the $\sim 790^{\circ} \mathrm{C} \mathrm{SO}_{2}$ peaks (François et al., 2015; Mcadam et al., 2020a). At higher temperatures, all soils showed a major release of $\mathrm{SO}_{2}$ beginning at $900^{\circ} \mathrm{C}$ which co-occurred with an endotherm, both of which are consistent with the thermal decomposition of crystalline sulfates (Ming et al., 2014; François et al., 2015). Since the samples were only heated to $\sim 1000^{\circ} \mathrm{C}$ for this work, the maximum peak height of this release cannot be ascertained. Across most samples, peak $\mathrm{SO}_{2}$ release temperatures generally did not co-occur with low-temperature $\left(\sim 400^{\circ} \mathrm{C}\right) \mathrm{CO}_{2}$ evolutions across the rest of the samples (Figure $\left.\mathrm{S} 1\right)$, so it is unlikely that sulfate minerals played a significant role in organic preservation in samples examined here. 


\subsection{Enrichment of organic carbon in surface layers of paleosols}

The near-surface horizons of all paleosols examined here had greater amounts of total organic carbon (TOC) relative to deeper horizons (Figure 9, Table 1). The highest amounts of $\mathrm{CO}_{2}$ released from decomposition of organic carbon $\left(150-500^{\circ} \mathrm{C}\right)$ were in the near surface $(\mathrm{A})$ horizons of all three paleosol types while subsurface layers of paleosols generally had lower quantities of evolved $\mathrm{CO}_{2}$ from organic carbon (Figure 3, Table 1). The A horizon of the Alfisol had TOC of $0.031 \pm 0.006$ wt. \% and progressively decreased to $0.002 \pm 0.007$ wt. $\%$ in the $\mathrm{C}$ horizon.
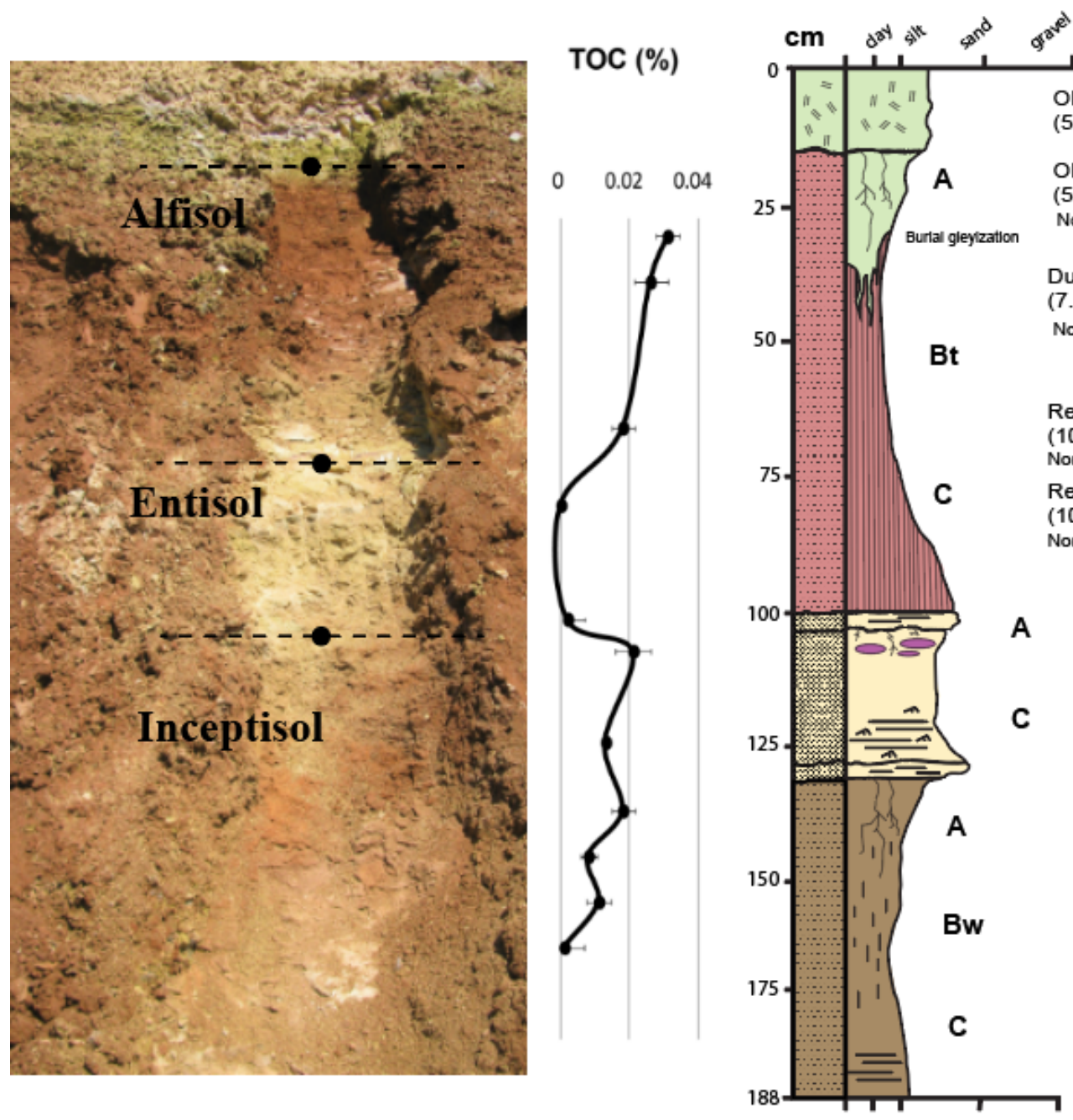
Olive Gray
$(5 Y 6 / 2)$

Olive Gray (5Y 6/2) Noncalcareous

Dusky Red (7.5YR 3/1) Noncalcareous

Red

(10R 3/1)

Noncalcareous

Red

(10R 3/1)

Noncalcareous

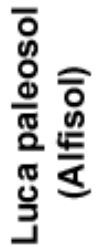

Figure 9. Trends of organic carbon enrichment in the near-surface horizons of three paleosols from the early Oligocene (33 Ma) middle Big Basin Member of the John Day Formation in eastern Oregon, USA. The surface (A) horizons of all three profiles had significantly $(\mathrm{P}>0.05)$ higher total organic carbon $(\mathrm{TOC})$ content relative to subsurface horizons ( $\mathrm{Bt}, \mathrm{Bw}$ and $\mathrm{C}$ horizons, respectively). Average TOC content of samples ( $\mathrm{n}=2)$ was determined by thermal and evolved gas analysis (oxygen as a carrier gas). gleization is an early diagenetic process in paleosols which involves the reduction of $\mathrm{Fe}^{3+}$ to $\mathrm{Fe}^{2+}$ by 
anaerobic microbes as a result of rapid burial (PiPujol and Buurman, 1994; Retallack, 2019). This is also thought to promote anaerobic decay of organic matter (Retallack, 2019), even in soils that originally formed under oxidizing conditions before burial. Typical burial gleization is closed system alteration, without depletion of total iron, and is usually limited to the surface horizons where organic matter is most concentrated. The surface horizon of the Alfisol examined in this work showed classic evidence of burial gleization with drab-colored mottles and tubular features predominantly in the A-horizon with minor radiation downward into the subsurface (Bt) horizon (Figure 9). Rapid emplacement of a biotite-bearing tuff on the paleosurface of the Alfisol may have led to gleization. Similar trends of near-surface TOC enrichment were noted in the Entisol and Alfisol (Table 1), but these samples lacked chemical $\left(\mathrm{FeO} / \mathrm{Fe}_{2} \mathrm{O}_{3}>0\right)$ and morphological evidence (drab green color) of burial gleization (Table S3). Previous work on terrestrial paleosols has shown positive and significant correlations between $\mathrm{Fe}^{2+}$ and $\mathrm{TOC}$ (Broz, 2020). This supports the interpretation that burial gleization, which increases $\mathrm{Fe}^{2+}$ in bulk samples, may have been associated with the preservation of organic carbon in the surface horizon of the Alfisol.

Organic carbon from organisms living in surface horizons of soils may have been preserved upon rapid burial of the paleosurface, and therefore the trend of surface enrichment may represent the preservation of endogenous organic carbon. Alternatively, diagenetic additions of carbon may have accumulated in near-surface layers of each profile. Major losses of endogenous organic carbon from early diagenetic burial decomposition of organic matter are common in paleosols that originally formed under oxidizing conditions such as those examined here (Retallack, 2019). Despite diagenetic additions and losses of organic carbon, the trend of surface enrichment of organic carbon remains apparent, even in soils that formed under strongly oxidizing conditions prior to burial. These results are consistent with other studies of paleosols where surface enrichment of organic carbon was observed (Rye and Holland, 2000; Watanabe et al., 2004; Liivamägi et al., 2018; Liu et al., 2020). However, it is possible that late diagenetic inputs of organics caused this enrichment, for example, by preferential flow and accumulation in the paleosurface of each profile. Considering the Holocene radiocarbon dates for these $\sim 33 \mathrm{Ma}$ paleosols (Table 1), results from this work cannot definitively rule out diagenesis as a mechanism for surface enrichment, though it is unlikely that early and/or late diagenetic additions of organic carbon would have preferentially accumulated in the near-surface horizons of these buried soils.

\subsection{Implications for Mars}

Recent work has considered putative paleosols on Mars as potential high priority environments for in-situ biosignature investigation (Hays et al., 2017) and Mars Sample Return (Bishop et al., 2018a). This is because the composition and properties of paleosols preserve evidence of paleoclimate, aqueous 
conditions, and life (Bishop et al., 2018a). A major finding of this study is that near-surface horizons of terrestrial paleosols appear to be a favorable location for SAM-EGA detection of organic carbon. Like modern soils, the surface layers of Mars-analog paleosols examined here show evidence of surface enrichment of organic carbon. Although the early diagenetic process of burial decomposition of organic matter has likely reduced the organic carbon content of these ancient soils by at least two orders of magnitude relative to modern soils (Broz, 2020), the enrichment of organic carbon in surface horizons ( $\sim 0.03$ wt. \%) and subsequent depletion in deeper layers ( $<0.01$ wt. \%) was readily observable a with SAM-EGA analog instrument.

Results from this study also have implications for interpreting the chemical and isotopic biosignature preservation potential of $\mathrm{Al}$ and $\mathrm{Fe}$ smectite-bearing weathering profiles on Mars. However, as discussed earlier, there are critical limitations to using terrestrial paleosols as analogs to interpret the organic preservation potential of paleosols on Mars, such as major differences in the types and properties of organic molecules deposited during soil formation. Irrevocable differences between Earth and Mars, including climate and a complex terrestrial biosphere, preclude direct comparisons. In any case, observations of refractory organic compounds that persist in terrestrial paleosols with Mars-like mineralogy provides a reference frame for interpreting future observations of putative weathering profiles on Mars. It is possible that clay minerals and/or amorphous phases in martian weathering profiles impart a similar control on the fate of organic carbon.

Results from this work also provide an initial framework for investigation and sampling of martian weathering profiles should they be encountered by current or future landed missions. Future insitu analysis of putative weathering profiles should begin at the surface and sample down the into the unaltered protolith. However, if the entire profile is not accessible for investigation (e.g., outcrop is at a topographic position inaccessible to the rover), the near-surface horizons of the profile, just below the uppermost burial layer, should be considered the highest priority target for remote sensing, contact science, and collection of a drilled sample for sample return to Earth.

\section{Conclusions}

The objectives of this study were a) to determine whether the organic carbon content of $\sim 30$ million-year-old paleosols can be detected with a thermal and evolved gas analyzer configured to operate like the SAM-EGA instrument onboard Curiosity Mars rover, and b) use radiocarbon $\left({ }^{14} \mathrm{C}\right)$ dating to constrain the age of organic carbon in bulk paleosol samples. Radiocarbon dating of organic carbon in four paleosol samples revealed the presence of recent and/or modern exogenous organic carbon. Samples from 0 - $20 \mathrm{~cm}$ were dated to $\sim 6,200$ years BP and had a fraction modern (fM) value of $\sim 0.4$, while a 
single deeper sample collected from $43 \mathrm{~cm}$ had a radiocarbon age of $\sim 14,600$ years BP and $\sim 0.16 \mathrm{fM}$. The presence of radiocarbon in paleosols could have resulted from the diagenetic addition of small amounts of modern $(<1 \mathrm{Ka})$ organic carbon which mixed with ${ }^{14} \mathrm{C}$-free endogenous organic carbon. Alternatively, a diagenetic event between 6-14 Ka could have introduced exogenous organics, possibly through groundwater alteration and/or precipitation-driven leaching of dissolved organic carbon. There may be a sampling depth (e.g., > 1 meter into the outcrop) which decreases or eliminates organic additions from exogenous sources. It is possible, however, that diagenesis has pervasively introduced exogenous organic carbon to deeper samples. Holocene-age radiocarbon dates supported the hypothesis that paleosols from the site contain exogenous organic carbon. These results highlight major challenges for determining the source(s) and age of organic matter in terrestrial paleosols. Radiocarbon dating should be used in future analog studies to help distinguish diagenetic organic inputs from original endogenous inputs.

SAM-EGA-like characterization of paleosols showed evolutions of $\mathrm{CO}, \mathrm{NO}, \mathrm{CO}_{2}$, and organic fragments. Coevolutions of $\mathrm{CO}_{2}$ and organic fragments at $\sim 400^{\circ} \mathrm{C}$ suggested the presence of refractory organic carbon. However, like other oxidized terrestrial paleosols of Cenozoic age and older, only trace amounts $(<0.1$ wt. \%) of organic carbon was detected, which most likely was a result of diagenetic decomposition of organic matter over geological time scales. Many samples examined in this work typically contained very low amounts $(\sim 0.01 \mathrm{wt} . \%)$ of organic carbon, but these low values were nevertheless detectable by SAM-like evolved gas analysis of bulk samples. These results suggest the organic fraction of potential martian weathering profiles may be detectable with evolved gas analysis, even if organic concentrations are low.

A major result of this work was that organic carbon was concentrated in near-surface horizons of paleosols while deeper horizons were depleted in organic carbon. Like modern soils, these ancient soils were enriched in organic carbon in near-surface horizons, and it appears that this trend persisted in these samples despite burial decomposition of organic carbon over geological time scales. Alternatively, diagenesis could have pervasively introduced exogenous organic carbon, but it is unlikely such organic contamination would preferentially accumulate in the surface layers of each successive buried soil profile. Surface enrichment of organic carbon in possible weathering profiles on Mars may therefore constitute a putative chemical biosignature. This work demonstrates that analytical techniques similar to SAM-EGA can detect trace amounts of organic carbon in complex pedogenic mineral matrices. The search for past life on ancient land surfaces of Mars should include targeting Martian weathering profiles for in-situ biosignature investigation and Mars Sample Return.

\section{Additional Information}




\section{Acknowledgements}

This work was performed on the ancestral homelands of the Numu, Cayuse, Umatilla, Walla Walla, and Confederated Tribes of the Warm Springs who were present before western settlement. Many thanks to Elizabeth Rampe and Paul Niles for the opportunity to work on this project and for providing research direction during a summer internship. Megan Barrington and Barry Hughes assisted with fieldwork and entertained thoughtful discussion. Angela Olsen, Marshall Styczinski, Paul Regensberger and Joe Caggiano reviewed early versions of the manuscript. Funding to A.P.B. from the National Science Foundation, Geological Society of America, The Clay Minerals Society, The Society of Sedimentary Geology, and the Central Oregon Geoscience Society aided in the completion of this project.

\section{Author Contribution Statement}

A.P.B and J.V.C designed the study, performed all laboratory analyses and drafted the manuscript. J.V.C, D.W.M, P.D.A, and B.S contributed to data analysis and interpretation. B.H.H identified similarities between Mars and Oregon paleosols and assisted with fieldwork and data interpretation. L.C.R.S provided radiocarbon analyses and interpreted the data. J.V.C, P.D.A, B.S, D.W.M, and L.C.R.S supervised the project. A.P.B drafted all figures. All authors contributed to the manuscript.

\section{Author Disclosure Statement}

No competing financial interests exist.

\section{Data Availability Statement}

All data supporting the conclusions can be found within the article and in the following repository: Mendeley Data, V4, DOI: 10.17632/bkvcff9dw8.1. All raw data to reproduce EGA traces are included in the Mendeley repository (https://data.mendeley.com/datasets/bkvcff9dw8/1).

\section{References}

Alekseeva, T. V, Zolotareva, B.N., and Kolyagin, Y.G., 2019, Nonhydrolyzable Part of Soil Organic Matter in Buried and Modern Soils: Eurasian Soil Science, v. 52, p. 632-643, doi:10.1134/S1064229319060024.

Amundson, R., 2018, Meteoric water alteration of soil and landscapes at Meridiani Planum, Mars: Earth and Planetary Science Letters, v. 488, p. 155-167, doi:10.1016/j.epsl.2018.02.012.

Apesteguia, M., Plante, A.F., and Virto, I., 2018, Methods assessment for organic and inorganic carbon quantification in calcareous soils of the Mediterranean region: Geoderma Regional, v. 12, p. 39-48, doi:10.1016/j.geodrs.2017.12.001. 
Archer, P.. et al., 2014, Abundances and implications of volatile-bearing species from evolved gas analysis of the Rocknest aeolian deposit, Gale Crater, Mars: Journal of Geophysical Research : Planets, p. 237-254, doi:10.1002/2013JE004493.Received.

Balco, G., Stone, J.O.H., and Mason, J.A., 2005, Numerical ages for Plio-Pleistocene glacial sediment sequences by $\mathrm{Al} / 10 \mathrm{Be}$ dating of quartz in buried paleosols: Earth and Planetary Science Letters, v. 232, p. 179-191, doi:10.1016/j.eps1.2004.12.013.

Beaty, D.W., Grady, M.M., Mcsween, H.Y., Sefton-Nash, E., Carrier, B.., Altieri, F., and Al., E., 2019, The potential science and engineering value of samples delivered to Earth by Mars sample return: Meteoritics \& Planetary Science, v. 671, p. 667-671, doi:10.1111/maps.13232.

Bestland, E.., 1997, Alluvial Terraces and Paleosols As Indicators Of Early Oligocene Climate Change (John-Day Formation, Oregon): Journal Of Sedimentary Research, v. 67, p. 840855, doi:10.1306/D4268653-2B26-11D7-8648000102C1865D.

Bestland, E.A., 2002, Fossil Andisols identified with mass-balance geochemistry (Oligocene John Day Formation, Oregon, U.S.A.): Journal of Sedimentary Research, v. 72, p. 673-686, doi:10.1306/021802720673.

Bishop, J.L. et al., 2018a, Potential high priority subaerial environments for Mars sample return: Proceedings of the Second International Mars Sample Return Conference, v. 2071, doi:2018LPICo2071.6043I.

Bishop, J.L., Fairén, A.G., Michalski, J.R., Gago-duport, L., Baker, L.L., Velbel, M.A., Gross, C., and Rampe, E.B., 2018b, Surface clay formation during short-term warmer and wetter conditions on a largely cold ancient Mars: Nature Astronomy, v. 2, p. 206-213, doi:10.1038/s41550-017-0377-9.

Bishop, J.L., Gross, C., Danielsen, J., Parente, M., Murchie, S.L., Horgan, B., Wray, J.J., Viviano, C., and Seelos, F.P., 2020, Multiple mineral horizons in layered outcrops at Mawrth Vallis, Mars, signify changing geochemical environments on early Mars: Icarus, v. 341, p. 113634, doi:10.1016/j.icarus.2020.113634.

Bishop, J.L., Loizeau, D., Mckeown, N.K., Saper, L., Dyar, M.D., Des, D.J., Parente, M., and Murchie, S.L., 2013, What the ancient phyllosilicates at Mawrth Vallis can tell us about possible habitability on early Mars: Planetary and Space Science, v. 86, p. 130-149, doi:10.1016/j.pss.2013.05.006.

Bishop, J.L., and Rampe, E.B., 2016, Evidence for a changing Martian climate from the mineralogy at Mawrth Vallis: Earth and Planetary Science Letters, v. 448, p. 42-48, doi:10.1016/j.eps1.2016.04.031.

Broz, A.P., 2020, Organic Matter Preservation in Ancient Soils of Earth and Mars: Life, v. 10, doi:doi:10.3390/life10070113.

Broz, A.P., Clark, J.., Archer, P.D., Sutter, B., Ming, D.W., Tu, V.M., Silva, L.C.R., and Horgan, B.H., 2021a, Thermal and Evolved Gas Analysis of Mars-analog Paleosols, in Lunar and Planetary Science Conference, v. 2136, p. 5-6.

Broz, A.P., Clark, J.V., Archer, P.., Sutter, B., Tu, V.M., Silva, L.C.R., and Horgan, B.H.N., 2021b, Radiocarbon dating of Mars-analog paleosols reveals contamination with exogenous organic carbon, in Terrestrial Analogs, v. 8094. 
Cannon, K.M., Sutter, B., Ming, D.W., Boynton, W. V., and Quinn, R., 2012, Perchlorate induced low temperature carbonate decomposition in the Mars Phoenix Thermal and Evolved Gas Analyzer (TEGA): Geophysical Research Letters, v. 39, p. 2-6, doi:10.1029/2012GL051952.

Carter, J., Loizeau, D., Mangold, N., Poulet, F., and Bibring, J., 2015, Widespread surface weathering on early Mars : A case for a warmer and wetter climate: Icarus, v. 248, p. $373-$ 382, doi:10.1016/j.icarus.2014.11.011.

Danielson, J.., Bishop, J.., Usabel, G.S., Miura, J.., Sessa, A.., Wray, J.., Itoh, Y., Parente, M., and Murchie, S.., 2019, Characterization of outcrops containing "doublet" spectra at Mawrth Vallis, Mars: Lunar and Planetary Science Conference, v. 2019, p. 1-179, doi:10.1029/2008g.

Dynarski, K.A., Bossio, D.A., and Scow, K.M., 2020, Dynamic Stability of Soil Carbon: Reassessing the "Permanence" of Soil Carbon Sequestration: Frontiers in Environmental Science, v. 8, doi:10.3389/fenvs.2020.514701.

Eigenbrode, J.L. et al., 2018, Organic matter preserved in 3-billion-year-old mudstones at Gale crater, Mars: Science, v. 360, p. 1096-1101, doi:10.1126/science.aas9185.

Ewing, S.A., Macalady, J.L., Warren-Rhodes, K., McKay, C.P., and Amundson, R., 2008, Changes in the soil $\mathrm{C}$ cycle at the arid-hyperarid transition in the Atacama Desert: Journal of Geophysical Research:, v. 113, p. 1-16, doi:10.1029/2007JG000495.

Finke, N. et al., 2019, Mesophilic microorganisms build terrestrial mats analogous to Precambrian microbial jungles: Nature Communications, v. 10, p. 1-11, doi:10.1038/s41467-019-11541-x.

Fornaro, T., Steele, A., and Brucato, J.R., 2018, Catalytic/protective properties of martian minerals and implications for possible origin of life on mars: Life, v. 8, p. 1-41, doi:10.3390/life8040056.

François, P., Szopa, C., Buch, A., Coll, P., Mcadam, A.C., Mahaffy, P.R., Freissinet, C., Glavin, D.P., and Cabane, M., 2015, Magnesium sulfate as a key mineral for the detection of organic molecules on Mars using pyrolysis: Journal of Geophysical Research - Planets, p. 61-74, doi:10.1002/2015JE004884.Received.

Freissinet, C. et al., 2015, Organic molecules in the Sheepbed Mudstone, Gale Crater, Mars: Journal of Geophysical Research : Planets, v. 120, p. 495-514, doi:10.1002/2014JE004737.Received.

Fremd, T.J., 1996, Data Quality in Terrestrial Assemblages: Perspectives from Volcaniclastic Sequences of the John Day Basin, Oregon: The Paleontological Society Special Publications, v. 8, p. 131-131, doi:10.1017/s2475262200001337.

Gay, A.., and Grandstaff, D.E., 1980, Chemistry and mineralogy of precambrian paleosols at elliot lake, ontario, canada: Precambrian Research, v. 12, p. 349-373.

Goesmann, F. et al., 2017, The Mars Organic Molecule Analyzer (MOMA) Instrument: Characterization of Organic Material in Martian Sediments: Astrobiology, v. 17, p. 655685, doi:10.1089/ast.2016.1551.

Hays, L.E., Graham, H. V., Des Marais, D.J., Hausrath, E.M., Horgan, B., McCollom, T.M., Parenteau, M.N., Potter-McIntyre, S.L., Williams, A.J., and Lynch, K.L., 2017, 
Biosignature Preservation and Detection in Mars Analog Environments: Astrobiology, v. 17, p. 363-400, doi:10.1089/ast.2016.1627.

Homann, M. et al., 2018, Microbial life and biogeochemical cycling on land 3,220 million years ago: Nature Geoscience, v. 11, p. 665-671, doi:10.1038/s41561-018-0190-9.

Horgan, B.H.N., 2013, Climate change and a sequence of habitable ancient surface environments preserved in pedogenically altered sediments at Mawrth Vallis, Mars., in Lunar and Planetary Science Conference, p. 3059.

Horgan, B., 2016, Strategies for Searching for Biosignatures in Ancient Martian Sub-Aerial Surface Environments: Biosignature Preservation and Detection in Mars Analog Environments, p. 7463, doi:10.1089/ast.2016.1627.

Horgan, B.H.N., Anderson, R.B., Dromart, G., Amador, E.S., and Rice, M.S., 2020, The mineral diversity of Jezero crater : Evidence for possible lacustrine carbonates on Mars: Icarus, v. 339, p. 113526, doi:10.1016/j.icarus.2019.113526.

Horgan, B., Bishop, L., Christensen, P.R., and Bell, J.F., 2012, Potential ancient soils preserved at Mawrth Vallis from comparisons with Eastern Oregon paleosols: Implications for Early Martian Climate: Third Conference on Early Mars, v. 7074, p. 12-13.

Horgan, B., Rutledge, A., and Rampe, E.., 2018, Clay mineralogy and crystallinity as a climatic indicator: Evidence for both cold and temperate conditons on early Mars: 46th Lunar and Planetary Science Conference, p. 3-4, doi:10.1029/2006.

Ivanov, M.A., Slyuta, E.N., Grishakina, E.A., and Dmitrovskii, A.A., 2020, Geomorphological Analysis of ExoMars Candidate Landing Site Oxia Planum: Solar System Research, v. 54, p. 1-14, doi:10.1134/S0038094620010050.

Kleber, M., Bourg, I.C., Coward, E.K., Hansel, C.M., Myneni, S.C.B., and Nunan, N., 2021, Dynamic interactions at the mineral-organic matter interface: Nature Reviews Earth and Environment, v. 2, p. 402-421, doi:10.1038/s43017-021-00162-y.

Kleber, M., Mikutta, R., Torn, M.., and Jahn, R., 2005, Poorly crystalline mineral phases protect organic matter in acid subsoil horizons: European Journal of Soil Science, p. 717-725, doi:10.1111/j.1365-2389.2005.00706.x.

Kremer, B., Kaźmierczak, J., and Środoń, J., 2017, Cyanobacterial-algal crusts from Late Ediacaran paleosols of the East European Craton: Precambrian Research, doi:10.1016/j.precamres.2017.12.018.

Krull, E.S., and Retallack, G.J., 2000, 13C depth profiles from paleosols across the PermianTriassic boundary : Evidence for methane release: GSA Bulletin, v. 112, p. 1459-1472.

Kurth, V.J., MacKenzie, M.D., and DeLuca, T.H., 2006, Estimating charcoal content in forest mineral soils: Geoderma, v. 137, p. 135-139, doi:10.1016/j.geoderma.2006.08.003.

De la Rosa, J.M., González-Pérez, J.A., González-Vázquez, R., Knicker, H., López-Capel, E., Manning, D.A.C., and González-Vila, F.J., 2008, Use of pyrolysis/GC-MS combined with thermal analysis to monitor $\mathrm{C}$ and $\mathrm{N}$ changes in soil organic matter from a Mediterranean fire affected forest: Catena, v. 74, p. 296-303, doi:10.1016/j.catena.2008.03.004.

Lantz, C., Poulet, F., Loizeau, D., Riu, L., Pilorget, C., Carter, J., Dypvik, H., Rull, F., and Werner, S.C., 2020, Planetary Terrestrial Analogues Library project: 1. characterization of 
samples by near-infrared point spectrometer: Planetary and Space Science, v. 189, p. 104989, doi:10.1016/j.pss.2020.104989.

Lawrence, C.R., Schulz, M.S., Masiello, C.A., Chadwick, O.A., and Harden, J.W., 2021, The trajectory of soil development and its relationship to soil carbon dynamics: Geoderma, v. 403, doi:10.1016/j.geoderma.2021.115378.

Lehmann, J., and Kleber, M., 2015, The contentious nature of soil organic matter: Nature, p. 1-9, doi:10.1038/nature16069.

Lewis, J.M.T. et al., 2021, Pyrolysis of Oxalate, Acetate, and Perchlorate Mixtures and the Implications for Organic Salts on Mars: Journal of Geophysical Research: Planets, v. 126, doi:10.1029/2020JE006803.

Liivamägi, S., Rodoń, J., Bojanowski, M., Gerdes, A., Stanek, J.J., Williams, L., and Szczerba, M., 2018, Paleosols on the Ediacaran basalts of the East European Craton: a unique record of paleoweathering with minimum diagenetic overprint: Precambrian Research, doi:10.1016/j.precamres.2018.07.020.

Liu, J., He, H., Michalski, J., Cuadros, J., Yao, Y., Tan, W., Qin, X., Li, S., and Wei, G., 2020, Reflectance spectroscopy applied to clay mineralogy and alteration intensity of a thick basaltic weathering sequence in Hainan Island, South China: Applied Clay Science, p. 105923, doi:10.1016/j.clay.2020.105923.

Liu, J., Michalski, J.R., Tan, W., He, H., Ye, B., and Xiao, L., 2021a, Anoxic chemical weathering under a reducing greenhouse on early Mars: Nature as, doi:https://doi.org/10.1038/s41550-021-01303-5.

Liu, J., Michalski, J.R., and Zhou, M., 2021b, Intense subaerial weathering of eolian sediments in Gale crater, Mars: Science Advances, v. 7, doi:DOI: 10.1126/sciadv.abh2687.

Loizeau, D. et al., 2020, ExoMars 2020 Surface Mission: Choosoing a Landing Site: v. 2019, p. 2019-2020.

Loizeau, D., Mangold, N., Poulet, F., Bibring, J., Bishop, J.L., Michalski, J., and Quantin, C., 2015, History of the clay-rich unit at Mawrth Vallis, Mars: High- resolution mapping of a candidate landing site: Journal of Geophysical Research: Planets, p. 1820-1846, doi:10.1002/2015JE004894.Received.

Loizeau, D., Quantin-nataf, C., Carter, J., Flahaut, J., Thollot, P., Lozac, L., and Millot, C., 2018, Quantifying widespread aqueous surface weathering on Mars : The plateaus south of Coprates Chasma: Icarus, v. 302, p. 451-469, doi:10.1016/j.icarus.2017.11.002.

Mahaffy, P.R. et al., 2012, The sample analysis at mars investigation and instrument suite: Space Science Reviews, v. 170, p. 401-478, doi:10.1007/s11214-012-9879-z.

Marin-Spiotta, E., Chaopricha, N.T., Plante, A.F., Diefendorf, A.F., Mueller, C.W., Grandy, A.S., and Mason, J.A., 2014, Long-term stabilization of deep soil carbon by fire and burial during early Holocene climate change: Nature Geoscience, v. 7, p. 428-432, doi:10.1038/ngeo2169.

Matthewman, R., Cotton, L.J., Martins, Z., and Sephton, M.A., 2012, Organic geochemistry of late Jurassic paleosols ( Dirt Beds ) of Dorset , UK: Marine and Petroleum Geology, v. 37 , p. 41-52, doi:10.1016/j.marpetgeo.2012.05.009. 
1023

1024

1025

1026

1027

1028

1029

1030

1031

1032

1033

1034

1035

1036

1037

1038

1039

1040

1041

1042

1043

1044

1045

1046

1047

1048

1049

1050

1051

1052

1053

1054

1055

1056

1057

1058

1059

1060

1061

1062

1063

1064
Mcadam, A.., Sutter, B., Archer, P.., Franz, H.., and Eigenbrode, J.., 2020a, The chemistry and mineralogy of the Glen Torridon clay-bearing unit from Mars Science Laboratory Sample Analysis at Mars: 51st Lunar and Planetary Science Conference, v. 2243, p. 60-74.

Mcadam, A.C., Sutter, B., Archer, P.D., Franz, H.B., Wong, G.M., Lewis, J.M.T., Eigenbrode, J.L., and Stern, J.C., 2020b, Constraints on the Mineralogy and Geochemistry of Vera Rubin Ridge, Gale Crater, Mars, From Mars Science Laboratory Sample Analysis at Mars Evolved Gas Analyses: Journal of Geophysical Research : Planets, p. 1-26, doi:10.1029/2019JE006309.

Miller, K.B., McCahon, T.J., and West, R.R., 1996, Lower Permian (wolfcampian) paleosolbearing cycles of the U.S. Midcontinent: Evidence of climatic cyclicity: Journal of Sedimentary Research, v. 66, p. 71-84, doi:10.1306/D42682B6-2B26-11D78648000102C1865D.

Ming, D.W. et al., 2014, Volatile and Organic Compositions of Sedimentary Rocks in Yellowknife Bay, Gale Crater, Mars: Science Express, p. 1-15, doi:10.1126/science.1245267.

Nabhan, S., Wiedenbeck, M., Milke, R., and Heubeck, C., 2016, Biogenic overgrowth on detrital pyrite in ca. 3.2 Ga Archean paleosols: Geology, v. 44, p. 763-766, doi:10.1130/G38090.1.

Nelson, P.N., and Baldock, J.A., 2005, Estimating the molecular composition of a diverse range of natural organic materials from solid-state C NMR and elemental analyses: Biogeochemistry, v. 72, p. 1-34, doi:10.1007/s10533-004-0076-3.

Noe Dobrea, E.Z., McAdam, A.C., Freissinet, C., Franz, H., Belmahdi, I., Hammersley, M.R., and Stoker, C.R., 2016, Characterizing the mechanisms for the preservation of organics at the Painted Desert: Lessons for MSL, Exo-Mars, and Mars 2020: 47th Lunar and Planetary Science Conference, p. Abstract \#2796.

Otto, A., Shunthirasingham, C., and Simpson, M.J., 2005, A comparison of plant and microbial biomarkers in grassland soils from the Prairie Ecozone of Canada: Organic Geochemistry, v. 36, p. 425-448, doi:10.1016/j.orggeochem.2004.09.008.

PiPujol, M.D., and Buurman, P., 1994, The distinction between ground-water gley and surfacewater gley phenomena in Tertiary paleosols of the Ebro basin, NE Spain: Palaeogeography, Palaeoclimatology, Palaeoecology, v. 110, p. 103-113, doi:10.1016/0031-0182(94)90112-0.

Plante, A.F., Fernández, J.M., Haddix, M.L., Steinweg, J.M., and Conant, R.T., 2011, Biological, chemical and thermal indices of soil organic matter stability in four grassland soils: Soil Biology and Biochemistry, v. 43, p. 1051-1058, doi:10.1016/j.soilbio.2011.01.024.

Poulet, F., Gross, C., Horgan, B., Loizeau, D., Bishop, J.L., Carter, J., and Orgel, C., 2020, Mawrth Vallis, Mars: A Fascinating Place for Future In Situ Exploration: Astrobiology, v. 20, p. 1-36, doi:10.1089/ast.2019.2074.

Ramirez, R.M., Kopparapu, R., Zugger, M.E., Robinson, T.D., Freedman, R., and Kasting, J.F., 2014, Warming early Mars with CO2 and H2: Nature Geoscience, v. 7, p. 59-63, doi:10.1038/ngeo2000.

Rampe, E.., Morris, R. V, Ruff, S.W., Dehouck, E., Achilles, C.N., Ming, D.W., Bish, D.L., and Chipera, S.J., 2014, Amorphous phases on the surface of Mars: Eighth International Conference on Mars, p. 1-2. 
1065

1066

1067

1068

1069

1070

1071

1072

1073

1074

1075

1076

1077

1078

1079

1080

1081

1082

1083

1084

1085

1086

1087

1088

1089

1090

1091

1092

1093

1094

1095

1096

1097

1098

1099

1100

1101

1102

1103

1104

1105
Raynaud, X., and Nunan, N., 2014, Spatial ecology of bacteria at the microscale in soil: PLoS ONE, v. 9, doi:10.1371/journal.pone.0087217.

Reardon, P.N., Chacon, S.S., Walter, E.D., Bowden, M.E., Washton, N.M., and Kleber, M., 2016, Abiotic Protein Fragmentation by Manganese Oxide: Implications for a Mechanism to Supply Soil Biota with Oligopeptides: Environmental Science and Technology, v. 50, p. 3486-3493, doi:10.1021/acs.est.5b04622.

Retallack, G.J., 2016, Astropedology: palaeosols and the origins of life: Geology Today, v. 32, p. 172-178, doi:10.1111/gto.12149.

Retallack, G.J., 2014, Paleosols and paleoenvironments of early Mars: Geology, v. 42, p. 755758, doi:10.1130/G35912.1.

Retallack, G.J., 2019, Soil of the Past: Wiley Blackwell.

Retallack, G.J., Bestland, E.., and Fremd, T.., 2000, Eocene and Oligocene Paleosols of Central Oregon: Geological Society of America Special Paper, v. 344, p. 1-192, doi:10.1046/j.1365-3091.2001.0394c.x.

Retallack, G.J., and Krull, E.S., 1999, Landscape ecological shift at the Permian - Triassic boundary in Antarctica: Australian Journal of Earth Sciences, v. 46, p. 785-812.

Retallack, G.J., and Mao, X., 2019, Paleoproterozoic ( ca . 1 . 9 Ga ) megascopic life on land in Western Australia: Palaeogeography, Palaeoclimatology, Palaeoecology, v. 532, p. 109266, doi:10.1016/j.palaeo.2019.109266.

Retallack, G.J., and Noffke, N., 2019, Are there ancient soils in the 3 . 7 Ga Isua Greenstone Belt , Greenland? Palaeogeography, Palaeoclimatology, Palaeoecology, v. 514, p. 18-30, doi:10.1016/j.palaeo.2018.10.005.

Retallack, G.J., Wynn, J.G., and Fremd, T.J., 2004, Glacial-interglacial-scale paleoclimatic change without large ice sheets in the Oligocene of central Oregon: Geology, v. 32, p. 297300, doi:10.1130/G20247.1.

Rye, R., and Holland, H., 2000, Life associated with a 2 . 76 Ga ephemeral pond ?: Evidence from Mount Roe \# 2 paleosol: Geology, v. 28, p. 483-486, doi:10.1130/00917613(2000)28<483:LAWAGE>2.0.CO;2.

Schiller, M., Dickinson, W., Ditchburn, R.G., Graham, I.J., and Zondervan, A., 2009, Atmospheric $10 \mathrm{Be}$ in an Antarctic soil: Implications for climate change : Journal of Geophysical Research, v. 114, p. 1-8, doi:10.1029/2008jf001052.

Schmidt, M.W.I. et al., 2011, Persistence of soil organic matter as an ecosystem property: Nature, doi:10.1038/nature10386.

Sheldon, N.D., Retallack, G.J., and Tanaka, S., 2015, Geochemical Climofunctions from North American Soils and Application to Paleosols across the Eocene - Oligocene Boundary in Oregon Geochemical Climofunctions from North American Soils and Application to Paleosols across the Eocene-Oligocene Boundary in Or: The Journal of Geology, v. 110, p. 687-696, doi:10.1086/342865.

Smith, R.., and Horgan, B.H.N., 2021, Nanoscale Variations in Natural Amorphous and Nanocrystalline Weathering Products in Mafic to Intermediate Volcanic Terrains on Earth : Implications for Amorphous Detections on Mars: Journal of Geophysical Research: Planets, 
v. 126, p. 1-30, doi:10.1029/2020JE006769.

Smith, R.., Horgan, B., Rampe, E., and Dehouck, E., 2018a, The Composition of Amorphous Phases in Soils and Sediments on Earth and Mars: 49th Lunar and Planetary Science Conference 2018, p. 14-15.

Smith, R.J., Rampe, E.B., Horgan, B.H.N., and Dehouck, E., 2018b, Deriving Amorphous Component Abundance and Composition of Rocks and Sediments on Earth and Mars: Journal of Geophysical Research: Planets, v. 123, p. 2485-2505, doi:10.1029/2018JE005612.

Stern, J.C., Sutter, B., Freissinet, C., Navarro-González, R., Mckay, C.., and Archer, P.D., 2015, Evidence for indigenous nitrogen in sedimentary and aeolian deposits from the Curiosity rover investigations at Gale ...: PNAS, doi:10.1073/pnas.1420932112.

Sutter, B., Boynton, W. V., Ming, D.W., Niles, P.B., Morris, R. V., Golden, D.C., Lauer, H. V., Fellows, C., Hamara, D.K., and Mertzman, S.A., 2012, The detection of carbonate in the martian soil at the Phoenix Landing site: A laboratory investigation and comparison with the Thermal and Evolved Gas Analyzer (TEGA) data: Icarus, v. 218, p. 290-296, doi:10.1016/j.icarus.2011.12.002.

Sutter, B., Mcadam, A.., Mahaffy, P.., Ming, D.., Edgett, K.., Rampe, E.., Eigenbrode, J.., Franz, H.., and Freissinet, C., 2017, Evolved gas analyses of sedimentary rocks and eolian sediment in Gale Crater, Mars: Results of the Curiosity rover's sample analysis at Mars instrument from Yellowknife Bay to the Namib Dune: Journal of Geophysical Research : Planets, p. 2574-2609, doi:10.1002/2016JE005225.

Sweeney, K.E., Roering, J.J., and Ellis, C., 2015, Experimental evidence for hillslope control of landscape scale: Science, v. 349, p. 51-53, doi:10.1126/science.aab0017.

Szopa, C. et al., 2020, First Detections of Dichlorobenzene Isomers and Trichloromethylpropane from Organic Matter Indigenous to Mars Mudstone in Gale Crater, Mars : Results from the Sample Analysis at Mars Instrument Onboard the Curiosity Rover: v. 20, p. 292-306, doi:10.1089/ast.2018.1908.

Viviano-Beck, C.E. et al., 2014, Revised CRISM spectral parameters and summary products based on the currently detected mineral diversity on Mars: Journal of Geophysical Research: Planets, v. 119, p. 1403-1431, doi:10.1002/2014JE004627.

Watanabe, Y., Martin, J.E.., and Ohmoto, H., 2000, Geochemical evidence for terrestrial ecosystems 2.6 billion years ago: Nature, v. 408, doi:10.1038/35046052.

Watanabe, Y., Stewart, B.W., and Ohmoto, H., 2004, Organic- and carbonate-rich soil formation $\sim 2.6$ billion years ago at Schagen, East Transvaal district, South Africa: Geochimica et Cosmochimica Acta, v. 68, p. 2129-2151, doi:10.1016/j.gca.2003.10.036.

Williams, E.K., Fogel, M.L., Berhe, A.A., and Plante, A.F., 2018, Distinct bioenergetic signatures in particulate versus mineral-associated soil organic matter: Geoderma, v. 330, p. 107-116, doi:10.1016/j.geoderma.2018.05.024.

Ye, B., and Michalski, J.R., 2021, Precipitation-Driven Pedogenic Weathering of Volcaniclastics on Early Mars: Geophysical Research Letters, v. 48, p. 1-10, doi:10.1029/2020GL091551. 